\title{
SODEMME: A NATURAL CIRCULATION THERMAL-HYDRAULICS CODE FOR HTGR TRANSIENT ANALYSIS
}

\author{
LESTER G. EPEL
}

Date Published - August 1977

\author{
HTGR SAFETY EVALUATION DIVISION \\ DEPARTMENT OF APPLIED SCIENCE \\ BROOKHAVEN NATIONAL LABORATORY \\ ASSOCIATED UNIVERSITIES, INC. \\ UPTON, NEW YORK 11973
}

PREPARED FOR THE UNITED STATES NUCLEAR REGULATORY COMMISSION DIVISION OF REACTOR SAFETY RESEARCH, OFFICE OF NUCLEAR REGULATORY RESEARCH UNDER CONTRACT N0. EY-76-C-02-0016 


\section{DISCLAIMER}

This report was prepared as an account of work sponsored by an agency of the United States Government. Neither the United States Government nor any agency Thereof, nor any of their employees, makes any warranty, express or implied, or assumes any legal liability or responsibility for the accuracy, completeness, or usefulness of any information, apparatus, product, or process disclosed, or represents that its use would not infringe privately owned rights. Reference herein to any specific commercial product, process, or service by trade name, trademark, manufacturer, or otherwise does not necessarily constitute or imply its endorsement, recommendation, or favoring by the United States Government or any agency thereof. The views and opinions of authors expressed herein do not necessarily state or reflect those of the United States Government or any agency thereof. 


\section{DISCLAIMER}

Portions of this document may be illegible in electronic image products. Images are produced from the best available original document. 


\section{DISCLAIMER}

This report was prepared as an account of work sponsored by an agency of the United States Government. Neither the United States Government nor any agency Thereof, nor any of their employees, makes any warranty, express or implied, or assumes any legal liability or responsibility for the accuracy, completeness, or usefulness of any information, apparatus, product, or process disclosed, or represents that its use would not infringe privately owned rights. Reference herein to any specific commercial product, process, or service by trade name, trademark, manufacturer, or otherwise does not necessarily constitute or imply its endorsement, recommendation, or favoring by the United States Government or any agency thereof. The views and opinions of authors expressed herein do not necessarily state or reflect those of the United States Government or any agency thereof. 


\section{DISCLAIMER}

Portions of this document may be illegible in electronic image products. Images are produced from the best available original document. 


\title{
SODEMME: A NATURAL CIRCULATION THERMAL-HYDRAULICS CODE FOR HTGR TRANSIENT ANALYSIS
}

\author{
LESTER G. EPEL
}

Manuscript Completed - July 1977

Date Published - August 1977

HTGR SAFETY EVALUATION DIVISION This report was prepared as an account of work
sponsored by the United States Government. Neither the
United States nor the United States Department of
Energy, nor any of their employees, nor any of their
contractors, subcontractors, or their employees, makes
any warranty, express or implied, or assumes any legal
liability or responsibility for the accuracy, completeness
of usefulness of any information, apparatus, product ni
process distosed, or represents that its use would not
infringe privately owned rights. DEPARTMENT OF APPLIED SCIENCE BROOKHAVEN NATIONAL LABORATORY ASSOCIATED UNIVERSITIES, INC. UPTON, NEW YORK 11973

\section{PREPARED FOR THE UNITED STATES NUCLEAR REGULATORY COMMISSION DIVISION OF REACTOR SAFETY RESEARCH, OFFICE OF NUCLEAR REGULATORY RESEARCH UNDER CONTRACT NO. EY-76-C-02-0016}


NOTICE

This report was prepared as an account of work sponsored by the United States Government. Neither the United States nor the United States Nuclear Regulatory Commission, nor any of their emiployccs, nor any of their contractors, subcontractors, or their employees, makes any warranty, express or implied, or assumes any legal liability or responsibility for the accuracy, completeness or usefulness of any information, apparatus, product or process disclosed, or represents that its use would not infringe privately owned rights.

Printed in the United States of America Available from

National Technical Information Service U.S. Department of Commerce 5285 Port Royal Road Springfield, VA 22161

Price: Printed Copy $\$ 4.50 ;$ Microfiche $\$ 3.00$ 
1. INTRODUCTION

1.1 General Description

1.2 Program Execution

2. MAJOR FEATURES 3

3. METHOD OF SOLUTION

3.1 Conservation of Linear Momentum (Steady State) 6

3.2 Conservation of Mass . 9

3.3 Conservation of Energy 9

3.4 Conservation of Linear Momentum (Transient) 10

3.5 Pumping, Friction, and Heat Transfer 11

3.5.1 Pressure Increase Due to a Machine 11

3.5.2 Friction Factor 12

3.5.3 Heat Transfer Rate 13

3.5.3.1 Steady State Heat Transfer 13

3.5.3.2 Time Dependent Heat. Transfer 15

$\begin{array}{ll}\text { 4. DESCRIPTION OF INPUT } & 18\end{array}$

$\begin{array}{ll}\text { 5. SAMPLE PROBLEM } & 28\end{array}$

6. NOMENCLATURE - SYMBOLS USED IN EQUATIONS 30

$\begin{array}{ll}\text { ACKNOWLEDGEMENTS } & 32\end{array}$

FIGURES $1-6$

REFERENCES $\quad 50$

APPENDIX A - Subroutine HTRNSFR .

FIGURES A1-A2 62

APPENDIX B - Geometric Relations in Plena 63 


\section{ABSTRACT}

The SODEME code provides a Solution to the One Dimensional Energy, Mass and Momentum Equations for a system of "volumes" and "segments" that comprise a circulating system containing a gaseous coolant. Input consists of a description of the system's geometry, the user's choice of some control variables, specification of the initial and timedependent boundary conditions and setting various options for items such as pumping head, heat transfer and frictional effects. The program automatically finds the steady state solution corresponding to the initial conditions and then proceeds to compute the transient solution corresponding to the input boundary conditions.

The present code is designed to operate with helium as the coolant but can very easily be altered to function with any gas by changing a few program statements. It is somewhat unique in that it is particularly suitable for solving natural circulation problems. The program has been written in modular form so that applications to diverse systems can be accommodated in the future by rewriting the subroutine that computes the heat transfer in particular components of the system being studied. The version described in this report is applicable to the 3000 MWth HTGR design. 
Figure 2 User Options for Terms in the Balance Equations.

Figure $3 \quad$ Calculational Model for Sample Problem. 34

Figure 4 Input Listing for Sample Problem. 35

Figure 5 Thermal Barrier Cover Plate Temperature Response to Graphite Surface Temperature Increase.

Figure 6 Output Listing for Sample Problem.

Figure A-1 HTGR Unit Cell.

Figure A-2 Equivalent One-Dimensional Cell. 


\section{INTRODUCTION}

\subsection{General Description}

In support of the HTGR safety analysis effort, the transient natural circulation code SODEMME has been developed to predict thermalhydraulic conditions inside the reactor primary cooling system during events such as a loss of forced circulation (LOFC) incident. The primary coolant flow rate and the reactor vessel cavity surface temperatures, which this program computes, are important in determining the amount of fission product release, first to the cavity itself and then to the containment building from the primary circuit, in the aftermath of such an occurrence.

Existing codes that deal with HTGR fluid flow and heat transfer have either been designed for specific components (e.g., SUPERHEAT ${ }^{1}$,

$\operatorname{CORCON}^{2}$ ) or to simulate the entire power plant (e.g., $\operatorname{TAP}^{3}, \operatorname{RECA}^{4}, \mathrm{CHAP}^{5}$ ) with no emphasis on the details of primary circuit surface temperature evolution. Another class of thermal-hydraulic code is available that is neither specific for a given component nor intended to simulate entire systems. These codes are general purpose programs that solve general multichannel and/or network problems (e.g., POKE ${ }^{6}$, FLAC $^{7}$ ) but none of these have the characteristics that make them suitable to be converted into a transient, natural circulation code for HTGR application. SODEMME was developed to provide a means of computing flow rates and surface temperatures along a series of segments that are joined together to make a complete loop (i.e. the end of the last segment joins with the beginning of the first segment). Each of the segments may have their own individual effects on the flow and temperature of the circulating helium 
by virtue of their frictional and heat transfer characteristics. The code was planned so that the small pressure (and density) changes that are inherent in natural circulation processes could be accommodated; nevertheless, it is possible to include the effects of a mechanical circulator, such as a blower, in the computation. The major limitation of the program is that multichannel flow, in which the thermalhydraulic characteristics of the parallel paths are dissimilar, cannot be accommodated. However, if the parallel channels are identical, so that they can be replaced by an "equivalent" single segment, the problem then fits within the scope of the program.

\subsection{Program Execution}

SODEMME was written in Fortran IV for the Brookhaven National Laboratory CDC 7600 system, operating under Scope 2. With the present Dimension Statements it requires $32 \mathrm{~K}$ (octal) of small core memory to execute. The running of a problem requires that the core be preset to zero and utilizes a library file called CUBIC, which extracts the three roots of a cubic algebraic equation. The running time naturally depends on the problem definition and the user options chosen during input preparation. The sample problem, described in Section 5 of this report, required 415 seconds of execution time. With the accounting system currently in effect at the BNL Central Scientific Computing Center, and using a "normal" priority to run the problem, the approximate cost of solving the sample problem was $2 c$ per reactor second.

The program is available on magnetic tape or as a source or object deck from the Brookhaven National Laboratory HTGR.Safety Code Library. 


\section{MAJOR FEATURES}

SODEMME can be used to compute flow rates, temperatures, pressures, heat transfer, etc. in any closed circuit comprised of a number of connected segments which have specified geometry and frictional and heat transfer characteristics. All of the programming except the last subroutine, HTRNSFR, is rather general and written without regard to any specific system. HTRNSFR was written to simulate heat transfer in various components of the 3000 MWth HTGR primary circuit (core, plena, cross ducts, steam generator) and so is "hard-wired" for this specific design. Since the program is written in modular form, other gas-cooled systems ciuld be simulated by replacing HTRNSFR with another subroutine written to calculate heat transfer in components of that system. Alternatively, if the amount of heat transferred in components of such a system can be stated explicitly as a function of time, subroutine HTRNSFR is not required at al1. Furthermore, a system cooled by a gas other than helium could be considered by simply replacing a few of the gas constants in the code with those of the other gas.

The program usually starts a given problem by finding a steady state solution corresponding to specified initial conditions. Besides the geometric data supplied to the code during input, information on pumping, friction factor, and heat transfer for each segment must be specified. During steady state each of these quantities may be specified in either of two ways:

- The pressure change due to a "pump" can be a constant value or it may be specified in tabular form as a function of flow rate. 
- The friction factor can be a constant value or the code can compute it automatically from Moody's ${ }^{8}$ correlation.

- The heat transferred to the helium can be a constant value or can be computed by one of the pre-programmed options available in HTRNSFR.

These three quantities are important because they influence the momentum equation used by the steady state subroutine, STST, to obtain pressure drops around the circuit for a specified range of flow rates. The code ensures that for each flow rate considered, the temperature of the helium exiting the last segment equals the temperature of the helium entering the first segment within $1 \%$ (this criterion can be changed by altering EPS2 in the Fortran). After a range of flow rates and their corresponding pressure drops have been computed by STST, subroutine TERPOL selects the one flow rate that yields a net pressure drop around the complete circuit of zero. The steady state solution so derived is then utilized as the initial condition for the transient portion of the calculation.

The transient calculation, performed by subroutine TRNSNT, involves an accounting of mass and energy flows into and out of volumes. An explicit method of solution is used to advance the time for each volume and find updated values of density and specific energy at the end of the time step. These updated values facilitate the computation of thermodynamic pressures for each volume via the perfect gas laws. The new pressures, in turn, are used in the momentum equation to find new flow rates.

Because of the inherent differences in the algorithms used to obtain the steady state solution compared to those used for the transient portion, 
slight discrepancies in many of the variables occur when the transient part of the problem. "takes over" from the steady state solution. This artifact of the computation can be overcome by making the transient portion of the problem at first simulate the initial, time-independent conditions until all of the variables approach steady state values again. The actual transient can then be computed starting from this "new" steady state solution.

As in the case of the steady state computation, input information on pumping, friction factor, and heat transfer for each segment is essential during the transient portion of the calculation. Each of these quantities may be specified in either of three ways. The two input options used during the steady state portion of the problem are available during the transient calculation, but in addition, the pressure change due to a mechanical device, the friction factor, and the heat transfer to the helium may be specified in tabular form as a function of time. These quantities are specified for a number of discrete time steps in such a table and subroutine POLATE performs a Iinear interpolation to obtain values for intermediate times, as needed. The transient portion of the calculation continues by alternately updating pressures and flow rates. The code does mass and energy balances on all of the volumes, utilizing updated information on pumping, friction factor, and heat transfer and then computes thermodynamic pressures in those volumes. The code then uses these pressures to update flow rates in all of the segments. This process is continued until the specified completion time of the problem is reached. 


\section{METHOD OF SOLUTION}

SODEMME obtains a time-dependent thermal-hydraulic description of a closed circuit by integrating a set of differential equations that describe mass, momentum, and energy conservation. Auxiliary algebraic relationships dealing with pumping, frictional effects, and heat transfer, as well as with the equation of state for helium, are used in conjunction with the conservation equations. As in any computer program, the physical problem is broken up into discrete spacial and temporal increments. The fluid circuit is divided into an integral number of "segments" and "volumes" while time is divided into time steps, during which all of the parameters of the system are assumed to be constant. The formal representation of the conservation laws and their transformation to simpler forms, which are the bases for the main algorithms in SODEMME, are presented in this section.

\subsection{Conservation of Linear Momentum (Steady State)}

The general momentum theorem ${ }^{9}$ for a control volume states that the sum of the forces acting on the control volume is equal to the net rate of momentum efflux from the control volume plus the rate of accumulation of momentum within the control volume. Formally, this can be written as*

$$
\Sigma \vec{F}=\iint \vec{v} \rho(\vec{v} \cdot \vec{n}) d A+\frac{\partial}{\partial t} \iiint \dot{\rho} \vec{v} d \dot{V}
$$

where $\vec{n}$ is the outward directed (from the control surface) unit normal. This vector equation can be simplified to a scalar equation in the $\mathrm{x}$ direction if one is willing to consider only the one-dimensional aspects:

*See listing of abbreviations used in the equations in Section 6 . 


$$
\sum F_{x}=\iint \cdot v_{x} \rho(\vec{v} \cdot \vec{n}) d A+\frac{\partial}{\partial t} \iiint \rho v_{x} d V
$$

During steady state the time derivative vanishes and Equation (2) b.ecomes

$$
\sum F_{x}=\iint v_{x} \rho(\vec{v} \cdot \vec{n}) d A
$$

The left-hand side of Equation (3) has several possible components: pressure forces, forces due to a mechanical device in the control volume, frictional forces, and gravitational forces. If the direction of fluid flow along the control volume is the reference direction, Equation (3) can be written (see Figure 1)

$$
\begin{gathered}
\left(P_{i}-P_{i+1}\right) A+\Delta p_{p} A-f \frac{l}{D} \frac{w^{2}}{2 g_{c} \bar{\rho} A}-K \frac{w^{2}}{2 g_{c} \rho_{i}^{A}} \\
-\ell A \bar{\rho} \sin \theta=\frac{w^{2}}{g_{c} A}\left(\frac{1}{\rho_{i+1}}-\frac{1}{\rho_{i}}\right)
\end{gathered}
$$

Notice that the control volume is referred to as Segment $i$ in Figure 1 and that the segment is associated with two volumes, $i$ and $i+1$. Volume $i$ (cross hatched in Figure 1) is comprised of one half of segment $i$ and one half of the preceding segment. Volume $i+1$ consists of the other half of segment $i$ plus one half of the succeeding segment. Certain properties such as pressure, temperature, density, internal energy, enthalpy, etc. are considered to be associated with volumes in the program and indeed, are assumed concentrated at the volume nodal points. Other parameters such as flow area, equivalent diameter, length, relative roughness, angle of inclination, orifice constant, friction factor, pump head, heat input, flow rate, etc. are associated with segments and are 
constant over the length of the segment at any given time. The entire flow circuit is made up of overlapping segments and volumes of this nature." The reason for this will become apparent later when the mass and energy conservation equations are applied. While the momentum equation is applied to segments, as typified by Equation (4), the mass and energy equations are more readily applied to volumes.

Notice also that the frictional term involves the average density in the segment. The fourth term on the left hand side of Equation (4), which represents forces associated with entrance losses to the segment, depends on the fluid density at the inlet of the segment, however. This is somewhat arbitrary in that a force representing outlet losses from the segment could also be included. Instead, this latter term is included as the inlet loss for the succeeding segment. Equation (4) is combined with the gas laws so that it can be rewritten in terms of pressures and temperatures rather than in terms of pressures and densities. The temperatures are dependent only on the heat transferred to the segment and are thus readily calculable. By making use of such auxilary relations, and considering $P_{i}$ to be known, Equation (4) can be cast into a cubic equation in $\mathrm{P}_{i+1}$. During execution of the steady state portion of SODEMM, this cubic equation is solved segment by segment, starting with the input value of $P_{i}$ for the first segment, until $\mathrm{P}_{i+1}$ for the last segment is found. The program repeats this procedure for a range of flow rates and builds up a catalog of flow versus circuit-pressure-drop values. For a closed loop $\mathrm{P}_{i+1}$ for the last segment must equal $P_{i}$ for the first segment. Subroutine TERPOL finds the flow rate that satisfies this condition by linear interpolation 
among the cataloged values. This. flow rate and the corresponding pressures, temperatures, densities; etc. constitute the initial conditions for the transient portion of the computation.

\subsection{Conservation of Mass}

With respect to the control volume of Section 3.1, the law of conservation of mass states that the rate of accumulation of mass within the control volume equals the net rate of mass influx into that control volume. This rather obvious fact can be furmalized as

$$
\iint \rho(\vec{v} \cdot \vec{n}) d A+\frac{\partial}{\partial t} \iiint \rho d V=0
$$

The integral form of Equation (5) applied to volume $i$ in the one-dimensional approximation is

$$
\frac{\partial m_{i}}{\partial t}=w_{i-1}-w_{i}
$$

and is readily calculable since the flow rates in segments $i-1$ and $i$ are known. For a given time step, then, an updated mass (and therefore density) can be derived for each volume.

\subsection{Conservation of Energy}

One statement of the familiar first law of thermodynamics is 10 that the difference between heat added to a control volume and the work done by the fluid in a control volume equals the net rate of energy efflux from the volume plus the rate of energy accumulation within the volume. The formal representation of this law is

$$
\frac{\delta Q}{d t}-\frac{\delta W}{d t}=\iint e \cdot \rho(\vec{v} \cdot \vec{n}) d A+\frac{\partial}{\partial t} \iiint \text { e } \rho d V
$$

where $e$ is the specific total energy and $Q$ and $W$ are the heat into and work out of the control volume, respectively. The work term consists of 
pressure work, shaft work, and shear work. If (as is true for the control volumes used in SODEMME) all parts of the control surface not at fixed walls are normal to the velocity of any fluid crossing the surface, the shear work is zero. Further, in the absence of electricity, magnetism, and capillarity, the specific total'energy is comprised of kinetic, potential, and internal energies. The first two generally can be neglected in comparison with the third in this type of application and this approximation serves to further simplify Equation (7). The integrated, onedimensional form of the energy equation used for volume $i$ becomes

$$
\frac{\partial\left(m_{i} u_{i}\right)}{\partial t}=w_{i-1} h_{i-1}-w_{i} h_{i}+\frac{\delta Q_{i}}{d t}-\frac{\delta S_{i}}{d t}
$$

where $h$ is the specific enthalpy and $S$ is the shaft work. In natural circulation cases the shaft work is zero and consequently the last term can be neglected*. Equation (8) provides a means of updating the internal energy in the volumes that make up the loop during successive time steps, given the flow rates, enthalpies, and heat transferred. The internal energy so found, together with the updated density from Equation (6), makes it possible to compute an updated thermodynamic pressure for each volume. This pressure is then used to compute a new flow rate as described in the following section.

\subsection{Conservation of Linear Momentum (Transient)}

The one-dimensional momentum equation, represented by Equation (2), can be written in integral form for the time dependent case using the same

\footnotetext{
*Even when there is shaft work supplied to the gas by devices such as fans or blowers, that amount of energy usually is negligible compared to the other energy terms.
} 
principles as in Section 3.1

$$
\begin{aligned}
& \left(P_{i}-P_{i+1}\right) A+\Delta p_{p} A-f \frac{\ell}{D} \frac{w^{2}}{2 g_{c} \rho A}-K \frac{w^{2}}{2 g_{c} \rho_{i}^{A}} \\
& -\ell A \bar{\rho} \sin \theta=\frac{w^{2}}{g_{c} A}\left(\frac{1}{\rho_{i+1}}-\frac{1}{\rho_{i}}\right)+\frac{\ell}{g_{c}} \frac{\partial w}{\partial t}
\end{aligned}
$$

The time dependent term, which was not present in the steady state form (see Equation [4]), can be evaluated because all of the other terms in Equation (9) are now known. In this manner, new flow rates are established for each of the segments and then the cycle of updating densities and internal energies in the volumes is repeated. These lead to new volume pressures, which lead to new segment flow rates and so on.

\subsection{Pumping, Friction, and Heat Transfer}

The balance equations are used to continually update the quantities of interest in the circulating system as described above. However, the momentum equation requires values of pressure rise due to a mechanical device and of friction factors; the energy equation requires values of heat transferred to the volumes. These values are supplied as described below and a. summary of the user's options for supplying these terms to the code is given in Figure 2.

\subsubsection{Pressure Increase Due to a Machine}

During the steady state portion of the calculation, when the initial conditions are being found, there are two ways in which a pressure increase due to a mechanical device, such as a blower or circulator, can be specified. The user can specify some constant value during input preparation or alternatively may specify a curve of pressure increase 
versus flow rate. This curve is specified by inputting up to 10 pairs of data points. The code will interpolate to obtain pressure increases for flow rates between the tabular values by using subroutine POLATE*. During the transient portion of the calculation both of these input alternatives are available together with a third. The user may, if he desires, specify a pressure increase versus time curve in the same way as the pressure increase versus flow rate curve is specifled.

\subsubsection{Friction Factor}

The friction factor used in the momentum equation is defined by the Darcy-Weisbach ${ }^{12}$ equation

$$
\Delta \mathrm{p}=\mathrm{f} \frac{\ell}{\mathrm{D}} \frac{\rho \mathrm{v}^{2}}{2 \mathrm{~g}_{\mathrm{c}}}
$$

During the steady state portion of the computation there are two ways of specifying this parameter. The user has the choice of specifying some constant value during input preparation or, if he wishes, allowing the code to automatically compute $f$. This is done by subroutine FRICT**. Subroutine STST, using current values of pressure, temperature, and flow rate for any segment, calculates the corresponding Reynold's number for that segment. This information, together with the relative roughness for the segment, is used by FRICT to find the friction factor by reference to Moody's tables. During the transient part of the computation the two input

*This subroutine was adapted from the LWR thermal-hydraulic code RELAP-3B. See Reference 11. **This subroutine was adapted from the fluid flow analysis code FLAC. See reference 7 . 
specification choices are still available and in addition there is a third choice. Again, the user may specify a friction factor versus time curve by inputting up to 10 pairs of points that describe the curve.

\subsubsection{Heat Transfer Rate}

\subsubsection{Steady State Heat Transfer}

The heat transfer rate required by the energy conservation equation, is provided to the code during the steady state computation in one of two ways. The first method is by specifying some constant value of heat rate. The alternative is to allow the code to compute the heat transferred to the various segments via the built-in heat transfer algorithms contained in subroutine HTRNSFR. During the steady state analysis there are four options the user has available. The models for these options (and for the six options available during the transient analysis) are detailed in Appendix A and so will be only outlined here. These algorithms were written specifically with the 3000 MWth HTGR in mind and so can legitimately be used only in such a system. If a different system is under study the user must either specify the heat transfer rate explicitly or re-program this subroutine to reflect the characteristics of the other design.

Besides computing the segment heat transfer rates, the algorithms in HTRNSFR also return calculated segment surface temperatures. Of course if HTRNSFR is not called upon during program execution, the surface temperatures are not computed by the code and asterisks will appear in the output where surface temperatures are usually printed.

A brief description of the four steady state

options is given here. 
Option 1 - This option applies to the coolant channels in the core. The model is based on flow in a constant area, constant surface temperature channel with a constant heat transfer coefficient. The graphite channel surface temperature is specified during input and the fluid temperature tends to approach this temperature asymptotically.

\section{Option 2 - This option is based on flow in}

ducts that are lined with an HTGR-type thermal barrier. The temperature dependence of the kaowool thermal conductivity is taken into account and it is assumed that the cool side of the barrier is maintained at $100^{\circ} \mathrm{F}$.

$$
\text { Option } 3 \text { - This option computes the heat transfer }
$$

to the helium in the plenum when the heat transfer rate from the graphite reflector to the helium is specified during input. It provides the heat transfer contribution from the thermal barrier which is modeled as a circular disc whose cool side is maintained at $100^{\circ} \mathrm{F}$. Only convective heat transfer to the helium is considered from the thermal barrier and reflector surfaces. The lesser of these two surface temperatures is returned as the surface temperature for the segment. The method of defining segment parameters such as flow area, equivalent diameter, and length for this type of segment, which is needed during the input phase, is discussed in Appendix B.

$$
\text { Option } 4 \text { - This option 1s equivalent to Option } 3
$$

with only one difference. Instead of specifying the heat transfer contribution of the reflector to the helium explicitly, this option requires the reflector surface temperature to be specified during input instead. The rest of the modeling is as in option 3 . 


\subsubsection{Time Dependent Heat Transfer}

During the transient portion of the computation the heat transfer rate is supplied to subroutine TRNSNT in one of three ways for each segment. The first is, as in the case of steady state, by specifying some constant value during input. The code considers this constant to be applicable to the entire course of the time-dependent calculation if this option is chosen. The second alternative is to provide a curve of heat transfer rate versus time by specifying up to 10 pairs of points, just as in the time-dependent specification of pressure increase and/or friction factor. The third alternative is to allow the program to compute the transient heat transfer rate. Six options are provided for the user if he chooses this alternative as described below.

$$
\text { Option } 1 \text { - This option is the time-dependent }
$$

analog of Option 1 in Section 3.5.3.1. Instead of specifying the graphite channel surface temperature as some constant value during input as was done there, however, the channel surface temperature must be specified as a function of time. Up to 10 pairs of data points may be prescribed to define this function.

\section{Option 2 - This option is the time-dependent} analog of Option 2 in Section 3.5.3.1. First, the thermal barrier cover plate initial temperature is found from the steady state conditions. Then, assuming that all of the thermal resistance is in the insulation and all of the thermal capacitance is in the cover plate, the cover plate temperature and heat transfer to the helium is computed as a function of time by a forward difference technique. In this model the thermal conductivity of the insulation is assumed to be a constant. This treatment 
of the thermal barrier is used in Options 3 and 4, below also.

Option 3 - This option is the time-dependent analog of Option 3 in Section 3.5.3.1. Instead of specifying the heat transfer rate from the reflector as a constant, however, this heat transfer rate (which is subsequently combined with that from the thermal barrier) is specified as a function of time using up to 10 pairs of data points. The graphite reflector surface temperature is computed and compared to the thermal barrier cover plate temperature. The smaller of these is returned to TRNSNT as the segment surface temperature.

$$
\text { Option } 4 \text { - This option is the time-dependent }
$$

analog of Option 4 in Section 3.5.3.1. Instead of specifying the reflector surface temperature as a constant, however, this parameter must be stipulated as a function of time, using up to 10 pairs of data points. At any time the smaller of the two surface temperatures (thermal barrier or graphite reflector) is returned as the significant surface temperature.

$$
\text { Option } 5 \text { - This option provides a primitive }
$$

model for the transient temperature behavior in the steam generators/ reheaters. The entire assemblage of tubes, sheets, and shells in the economizers, evaporators, superheaters, and reheaters has been homogenized in this model. It is assumed that no steam/water is present in the assemblies during this portion of the transient. The metal is considered to be isothermal and changes temperature with time due solely to convective heat transfer with the helium. The thermal capacitance of the heat exchanger metal is thus taken into account in a rudimentary fashion. 
Option 6 - This option simulates transient

heat transfer in the HTGR core. A one-dimensional cell was designed that approximates the two-dimensional triangular cell typically used in HTGR heat transfer calculations. First the initial temperature profile is computed through the fuel and graphite in this cell. Then, from a power versus time curve supplied during input, the transient temperature distribution through the fuel and graphite is computed. The heat transfer to the helium is found at each time step by the convective boundary condition at the graphite-helium interface.

During the execution of these 6 time-dependent heat transfer options the user has the capability of using a time step larger than the time step used in the other parts of SODEMME. In this way he can axoid having the code do the laborious heat transfer calculations every time the mass, momentum, and energy equations are updated. The only restriction on the size of this time step has to do with numerical instabilities that could occur. This question is addressed in Appendix A where criteria on maximum time step sizes are developed. It is shown there that, in general, the stability criteria are not unduly restrictive for practical situations encountered in the HTGR and that time steps on the order of 100 times the "basic" time step are reasonable for the heat transfer calculations.

It is noted that when the user takes advantage of this opportunity to decrease computing time, the program updates the flow- or time-dependent pressure increase (Section 3.5.1), the flow- or time-dependent friction factor (Section 3.5.2), and the time-dependent 
heat transfer rate (Section 3.5.3.2) according to the same schedule. That is, if the heat transfer rate is updated every 50 time steps, for example, an updated friction factor will also be computed every 50 time steps, if automatic calculation of the friction factor is another of the chosen options.

\section{DESCRIPTION OF INPUT}

This section describes the input requirements for SODEMME.' The input is divided into the data needed for solution of the steady state portion and that needed for the transient part. It is possible to run only one or the other of these portions of the code, if desired.

There are, in general, 11 types of input cards required for the steady state part and 13 types of cards for the transient part. Some of these are not always necessary, depending on the problem definition. Most card types involve several individual cards, depending on the number of segments that require input in that category. When more than one card is required, they are inserted consecutively, starting with the one for the first segment and continuing with any others that may be required, until the one for the last segment has been included. The only card types that invariably need a single card are card types $1,2,11,12$, and 24. All of the others could, depending on the specific problem, require more than a single card.

The details of the input requirements follow. The first 11 card types are related to the steady state portion of the problem; the next 13 card types are concerned with the transient part. 
1. Title Card

TITLE

Any 80 column (or less) alphanumeric description to be printed as the heading on the output.

2. Control Parameter Card 3F10.5, 4 I10

WFIRST The smallest flow rate to be used in the steady state computation (pounds/sec).

WLAST

The largest flow rate to be used in the steady state computation (pounds/sec):

DELTAW

The difference between successive flow rates used in the series of computations starting with WFIRST (pounds/sec).

NMAX

The number of segments in the representation of the

NOSTST circuit. Up to a maximum of 30 .

NOTRAN

If the user does not wish to compute the steady state solution, this parameter is set to 1 .

IPUNCH If the user does not wish to compute the transient solution, this parameter is set to 1 . If relevant data at the end of the transient calculation is to be punched for possible restart of the problem, this parameter is set to 1 .

3. Segment Parameter Card I10, Al0, 6F10.5 (one for each segment)

J : Segment number (1 through 30).

SNAME Segment name (up to 10 characters).

A Cross sectional flow area of the segment (inch $\left.{ }^{2}\right)$. Equivalent diameter of the segment (inches). 
L

K

RELRUF

THETA
Length of the segment (feet).

Entrance loss coefficient of the segment (dimensionless).

The segment relative roughness (dimensionless).

The angle the segment makes, in the direction of

flow, with the rightward pointing horizontal

vector (degrees).

If NOSTST=1, then card types 4 through 11 are not required and the next card is card type 12 .

4. Segment Indicators Card

(one for each segment)

$7 I 10$, F10.5

INDPC

If the pressure increase due to a mechanical device

for this segment is to be a constant, this indicator

is set to 1 .

INDPVW

If the pressure increase due to a mechanicail device

for this segment is to be tabulated against flow

rate, this indicator is set to 1 .

INDFC

If the friction factor for this segment is to be a

constant, this indicator is set to 1 .

INDFVW

If the friction factor for this segment is to be computed automatically by the code, this indicator is set to 1 .

INDQC

If the heat transfer for this segment is to be a constant, this indicator is set to 1 .

INDQVW
If the heat transfer for this segment is to be computed automatically by the code, this indicator is set to 1 . 
NOPTSS

If INDQVW=1, this parameter must be set to the desired steady. state heat transfer option

(1 through 4).

HTCSS

If INDQVW=1, the steady state heat transfer coefficient is required (Btu/hr $\mathrm{ft}^{2} \mathrm{~F}$ ).

If INDPC=1 for any segment, a card of the following type for each such segment is required:

5. Constant Pressure Increase Card $\quad$ F10.5

PPUMP Pressure increase (pounds/in ${ }^{2}$ ).

If INDFC=1 for any segment, a card of the following type for each such segment is required.

6. Constant Friction Factor Card $\quad$ F10.5

F Friction factor (dimensionless).

If INDQC=1 for any segment, a card of the following type for each such segment is required.

7. Constant Heat Rate Card $\quad$ F10.5

Q Heat transfer rate to the helium (Btu/sec).

If INDPVW=1 for any segment, cards of the following type for each such segment are required*.

8. Pressure Increase vs. Flow Card $\quad$ Il0, 10X, 6F10.5/(8 F10.5)

NE The number of entries in the table (2 times the

*As many as 3 cards may be needed to specify the 10 pairs of data points that could be used to define a complete table for each segment. If exactly 3 pairs of data points are used for any segment, the single card used should be followed by one blank card. 


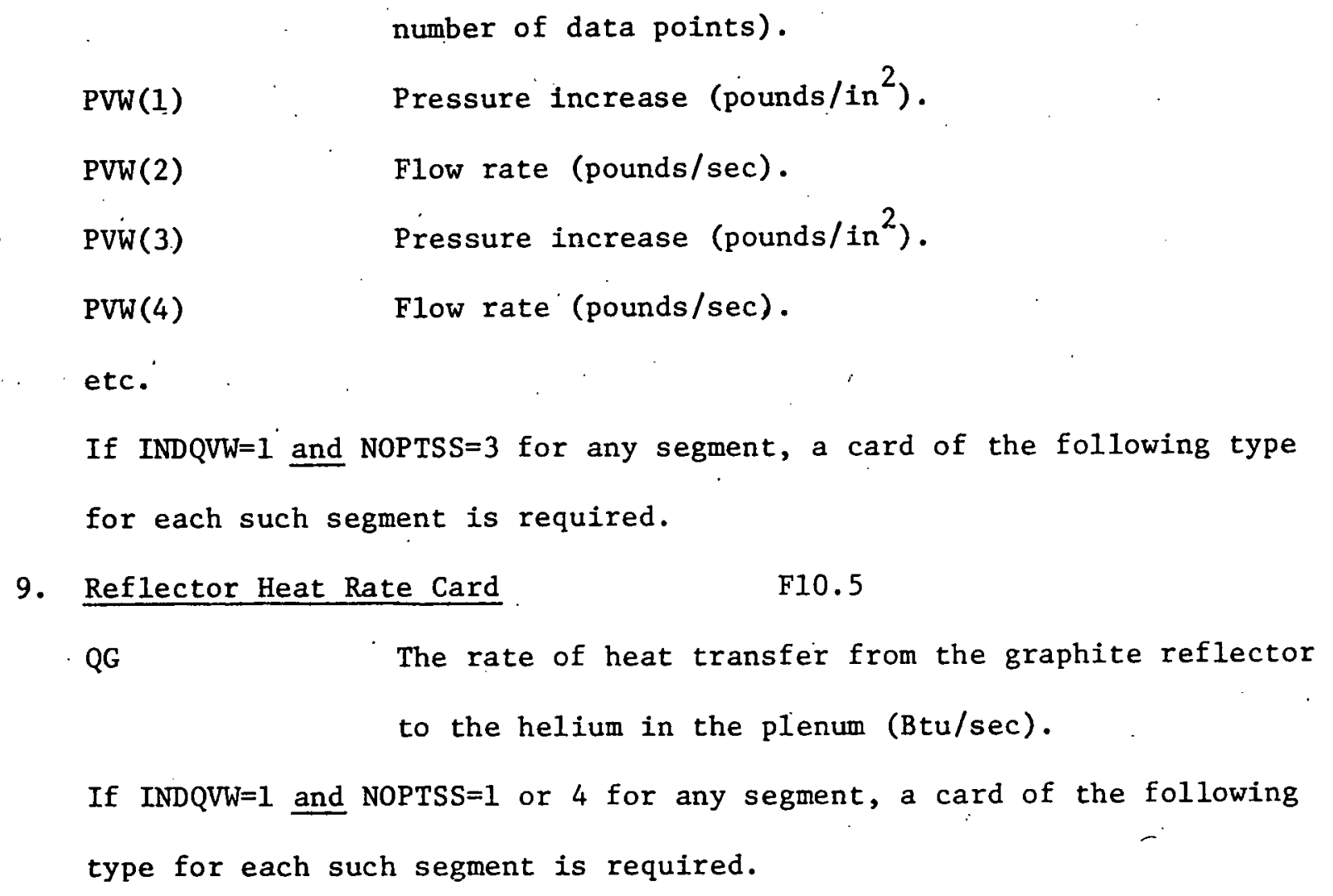

9. Reflector Heat Rate Card . F10.5 to the helium in the plenum (Btu/sec).

If INDQVW=1 and NOPTSS $=1$ or 4 for any segment, a card of the following type for each such segment is required.

10. Graphite Surface Temperature Card F10.5

TSG The graphite surface temperature (F).

11. Inlet Pressure/Temperature Card $2 F 10.5$

$P(1) \quad$ The inlet pressure to the first segment (pounds/in ${ }^{2}$ ).

$\mathrm{T}(1) \quad$ An estimate of the inlet temperature to the first segment (F).

This concludes the input for the steady state portion of the program.

The remaining cards constitute the input for the transient part.

12. Control Parameter Card $3 F 10.5,2110$

TFIRST The time at which the transient portion is considered to begin. This will be zero except for restart problems (sec). 
TILAST

The time at which it is desired to end the problem (sec).

DELTAT

The time step used in advancing the history of the problem (sec).

ICALC

The number of time steps that shall pass before pumping head, friction factors, and/or heat transfer effects are updated.

IPRINT The number of time steps that shall pass before the variables are printed as output.

13. Segment. Indicators Card

(onc for cach segment)

10I5, F10.5

INDPC

If the pressure increase due to a mechanical device for this segment is to be a constant, this indicator is set to 1 .

INDPVW

If the pressure increase die to a mechanical device for this segment is to be tabulated against flow rate, this indicator is set to 1 .

INDPVT

If the pressure increase due to a mechanical device for this segment is to be tabulated against time, this indicator is set to 1 .

INDFC If the friction factor for this segment is to be a constant, this indicator is set to 1 .

INDFVW If the friction factor for this segment is to be computed automatically by the code, this indicator is set to 1 . 
INDFVT

If the friction factor for this segment is to be tabulated against time, this indicator is set to 1 .

INDQC If the heat transfer for this segment is to be a constant, this indicator is set to 1 .

INDQVW

If the heat transfer for this, segment is to, be computed automatically by the code, this indicator is set to 1 .

INDQVT

If the heat transfer for this segment is to be tabulated against time, this indicator is set to 1 .

NOPTTR If INDQVW=1, this parameter must be set to the desired transient heat transfer option ( 1 through 6 ).

HTCTR If INDQVW=1, the transient heat transfer coefficient is required (Btu/hr $\mathrm{ft}^{2} \mathrm{~F}$ ).

If INDPC=1 for any segment, a card of the following type for each such segment is required.

14. Constant Pressure Increase Card $\quad$ F10.5

PPUMP Pressure increase (pounds/in ${ }^{2}$ ).

If INDFC=1 for any segment, a card of the following type for each such segment is required.

15. Constant Friction Factor Card $\quad$ F10.5

F $\quad$ Friction factor (dimensionless).

If INDQC=1 for any segment, a card of the following type for each such segment is required.

16. Constant Heat Rate Card F10.5 
If $I N D P V W=1$ for any segment, cards of the following type for each such segment are required*.

17. Pressure Increase vs. Flow Card $\quad I 10,10 \mathrm{X}, 6 \mathrm{~F} 10.5 /(8 \mathrm{~F} 10.5)$ NE The number of entries in the table ( 2 times the number of data points).

PVW(1) Pressure increase (pounds/in ${ }^{2}$ ).

PVW(2) Flow rate (pounds/sec).

PVW(3) Pressure increase (pounds/in ${ }^{2}$ ).

PVW(4) Flow rate (pounds/sec).

etc.

If INDPVT=1 for any segment, cards of the following type for each such segment are required*.

18. Pressure Increase vs. Time Card $\quad I 10,10 \mathrm{X}, 6 \mathrm{~F} 10.5 /(8 \mathrm{~F} 10.5)$

NE The number of entries in the table (2 times the number of data points).

PVT(1) Pressure increase (pounds/in ${ }^{2}$ ).

PVT(2) Time (sec).

PVT(3) Pressure increase (pounds/in ${ }^{2}$ ).

PVT(4) Time (sec).

etc.

If INDFVT=1 for any segment, cards of the following type for each such segment are required*.

19. Friction Factor vs. Time Card I10, 10X, 6F10.5/(8F10.5) NE The number of entries in the table (2 times the * See footnote on bottom of page 21 . 


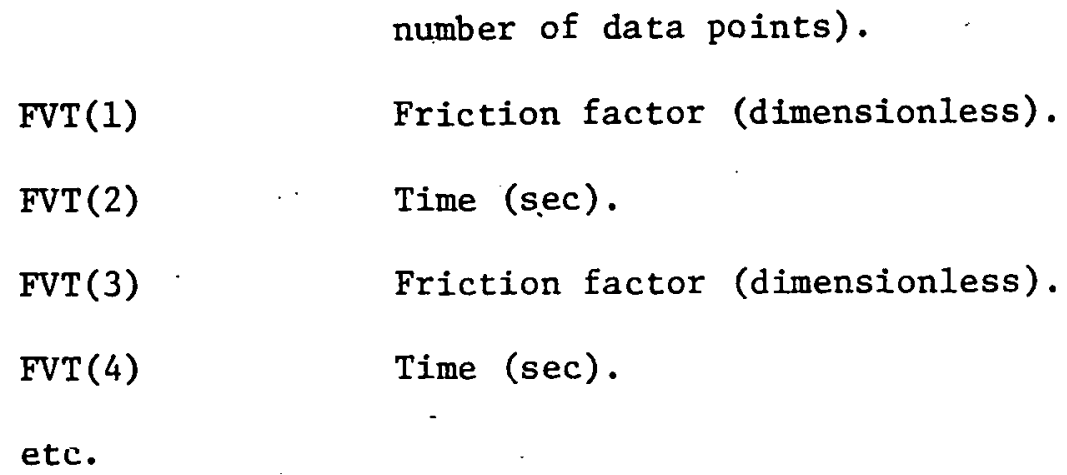


QGVT(4) Time (sec).

etc.

If INDQVW=1 and NOPTTR=1 or 4 for any segment, cards of the following type for each such segment are required*.

22. Graphite Surface Temperature vs. Time Card I10, 10X, 6F10.5/(8F10.5)

NE The number of entries in the table (2 times the number of data points).

TSGVT(1) Graphite surface temperature (F).

TSGVT(2) Time (sec).

TSGVT(3) Graphite surface temperature (F).

TSGVT (4) . Time (sec).

etc.

If INDQVW=1 and NOPTTR=5 for any segment; a card of the following type for each such segment is required.

23. Initial SG Metal Temperature Card $\quad$ F10.5

TSTEEL Initial temperature of the steel in the steam generators/reheaters (F). If this is made equal to zero (or left blank) the helium temperature at time $=0$ will be assigned to the metal.

If INDQVW=1 and NOPTTR=6 for any segment, a card of the following type for each such segment is required.

24. Fractional Power vs. Time Card $\quad$ I10, 10X, 6F10.5/(8F10.5) NE The number of entries in the table ( 2 times the number of data points).

* See footnote on bottom of page 21 . 


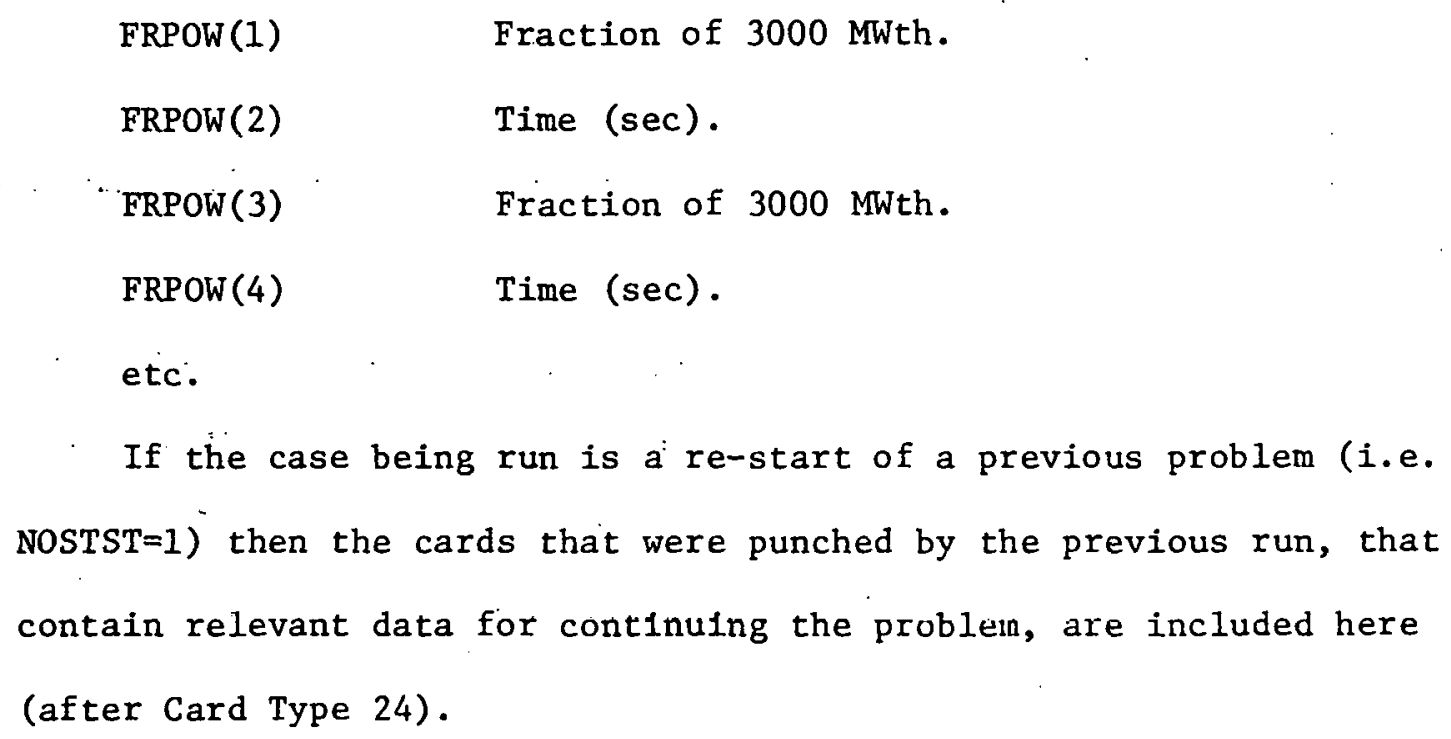

\section{SAMPLE PROBLEM}

The computational model for an illustrative problem is depicted in Figure 3. This model consists of 9 segments representing, in order of flow direction during natural circulation, the bottom plenum, the core, the upper plenum, the upper cross ducts, the outer flow annulii in the steam generators, the main steam generator bundles, the inner flow annulii in the steam generators, the reheater bundles, and the lower cross ducts. of an HTGR.

The numerical values used in the segment parameter cards are not intended to accurately represent the 3000 MWth HTGR. It proved very difficult to obtain design values for such components as the main steam generator bundle; for example, and so various types of information from diverse sources were blended together. For example, reference 1, pages 4-6, states that the design Reynold's number for the helium side in the main steam generator is on the order of 40000. Also, reference 13 gives 
the design helium velocity in the Fort St. Vrain main coil as 80 fps. Assuming that this velocity is representative of the HTGR main steam bundle, these two pieces of information make it possible to estimate the equivalent diameter of this segment in the model. Although some of the numerical values used may only approximate the true values, this sample problem nevertheless serves to illustrate the application of the computer program.

In the sample problem, the initial conditions are that the lower reflector, core, and upper reflector graphite are at $1000 \mathrm{~F}, 1500 \mathrm{~F}$, and $1700 \mathrm{~F}$, respectively, and that the main steam bundle removes $5000 \mathrm{Btu} / \mathrm{second}$ from the helium. Heat transfer Option 2 was selected for the upper and lower cross ducts, Option 1 was used for the core, and Option 4 for the top and bottom plena. Segments 5, 7, and 8 were assumed to be adiabatic. There was no pumping action in any segment and the friction factors were specified explicitly*.

After the steady state solution was derived, it was desired to let the code find a "new" steady state (see page 4) via the algorithm in subroutine TRNSNT. Thus the initial conditions were maintained for the first 1000 seconds into the transient. For the next 900 seconds (i.e. quarter hour) the lower reflector, core, and upper reflector graphite temperatures were assumed to ramp linearly to $1200 \mathrm{~F}, 1700 \mathrm{~F}$, and $1900 \mathrm{~F}$, respectively. *Actually, the sample problem was first run utilizing the option that calculates friction factors automatically. Then, in order to save computing time, the values of friction factors so computed by the program were used for the sample problem. 
All of the other boundary conditions were assumed to remain unchanged. The listing of the input for this problem is shown in Figure 4.

The resulting thermal barrier cover plate temperatures are shown in Figure 5 for this 15 minute transient. It is clear that the response of these surfaces is rather sluggish compared to the $200^{\circ} \mathrm{F}$ rise that the graphite surfaces underwent during the same time span. Because of this lag in following the increase in graphite temperature, the heat rejecting parts of the system, although increasing the amount of heat they extract from the helium, cannot keep pace with the increase in the amount of heat supplied to the helium. Reference to the next-to-last column in the output (Figure 6) for the transient part of the calculation indicates that whereas the net amount of heat into the gas was essentially zero at the beginning of the ramp, this parameter had risen to about $700 \mathrm{Btu} / \mathrm{second}$ at the end of the 15 minute time interval. The corresponding rise in fluid temperature and pressure throughout the system is evident from the second and third columns in the output.

\section{NOMENCLATURE - SYMBOLS USED IN EQUATIONS}

Symbols

a

A

b

C

$\mathrm{C}_{\mathrm{s}}$

D constant used in thermal conductivity equation

area for heat transfer or fluid flow

constant used in thermal conducivity equation

specific heat of gas

specific heat of solid

equivalent diameter 
$P$

q

s

$\Delta \mathrm{t}$

$\mathrm{T}$

$\Delta \mathrm{x}$

$\mathrm{u}$

$\mathrm{v}$

$\mathrm{V}$

$\mathbf{w}$

\section{friction factor}

force

volumetric heat generation rate gravitational constant

heat transfer coefficient

thermal conductivity

entrance loss coefficient

length of segment

mass of fluid

mass of steel

pressure difference

wetted perimeter of segment

pressure

rate of heat transfer

distance between noda1 points

time step

temperature

thickness of kaowool insulation

internal energy

velocity

volume

rate of mass flow

Subscripts

c

coolant water

f

fluid (helium) 


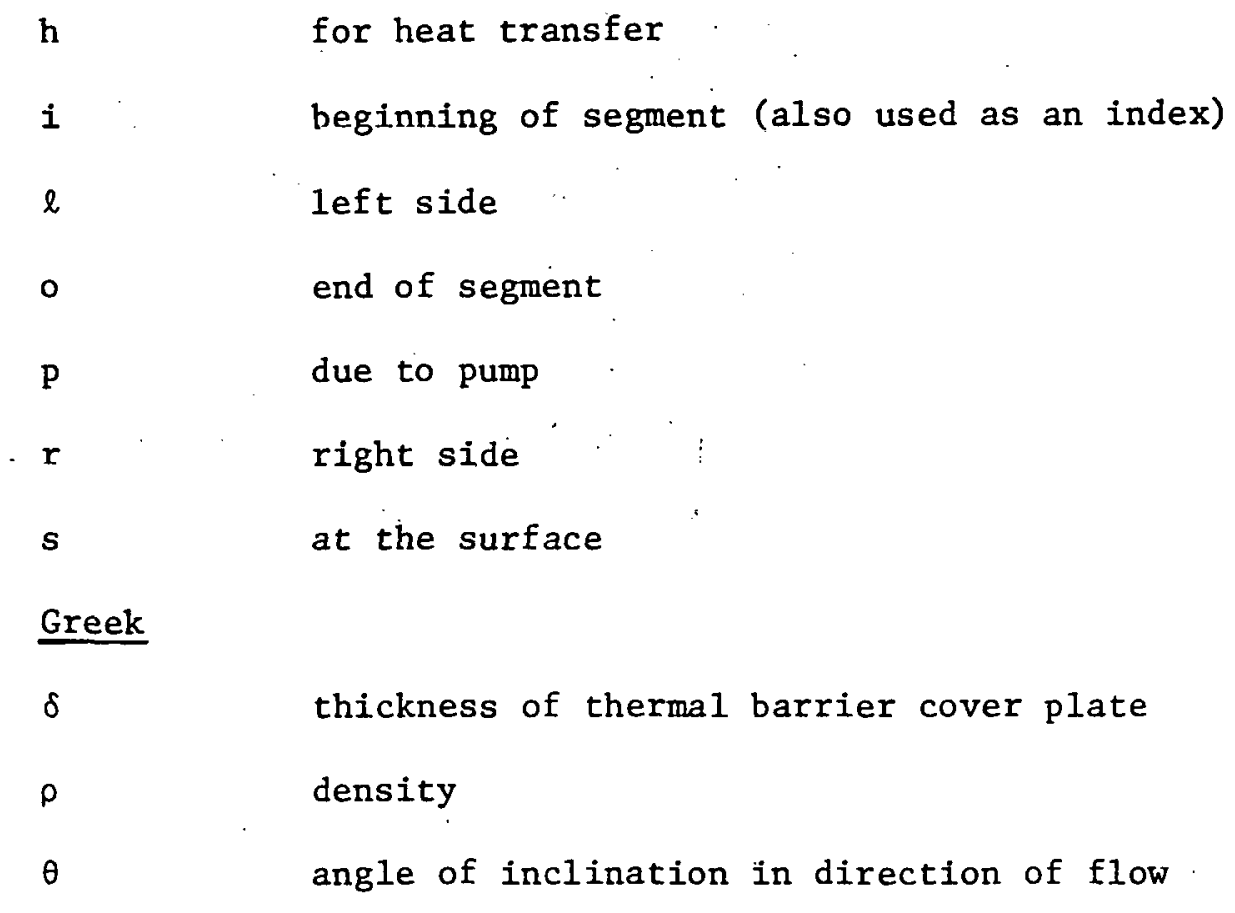

\section{ACKNOWLEDGEMENTS}

The author would like to thank C. Sastre, of the HTGR Safety Division, who originally suggested that the problem of cavity surface temperature evolution during natural convection be studied. Also of great benefit were a number of therapeutic discussions with him during the development of the code.

Thanks are also due to J. Beerman and J. Colman of the HTGR Safety Division for finding some of the inevitable "bugs" that accompany every computer program, and to Mrs. Grace Searles for an excellent typing job. 


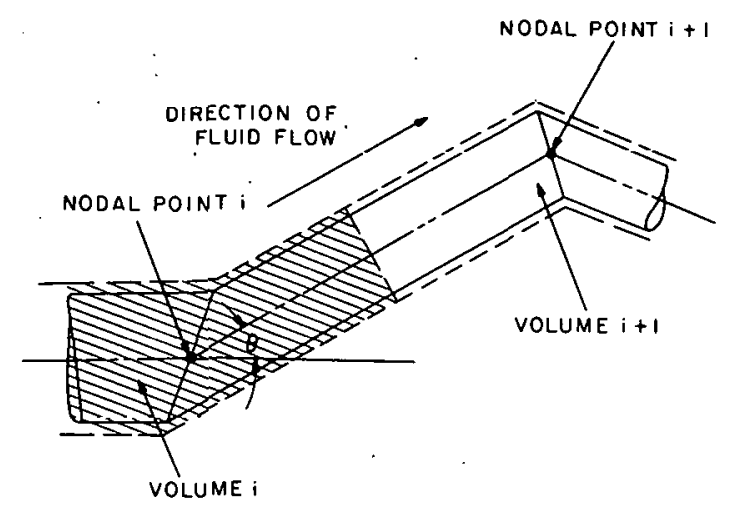

Figure 1. Segment 1.

(Steady State Portion)

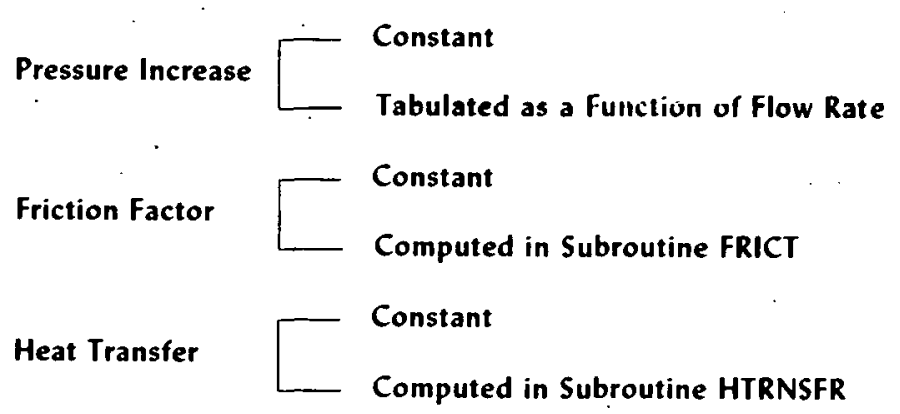

(Transient Portion)

Pressure Increase $\left[\begin{array}{l}\text { Constant } \\ \text { Tabulated as a Function of Flow Rate } \\ \text { Tabulated as a Function of Time }\end{array}\right.$

Friction Factor $\left[\begin{array}{l}\text { Constant } \\ \text { Computed in Subroutine FRICT } \\ \text { Tabulated as a Function of Time }\end{array}\right.$

Heat Transfer $\left[\begin{array}{l}\text { Constant } \\ \text { Computed in Subroutine HTRNSFR } \\ \text { Tabulated as a Function of Time }\end{array}\right.$

Figure 2. User options for terms in the balance equations. 


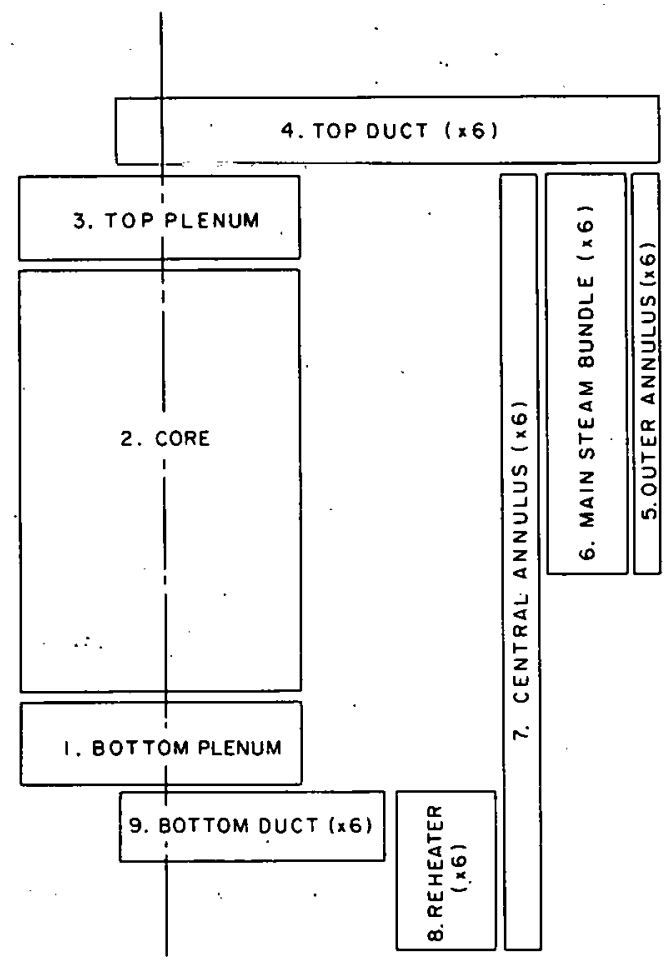

Figure 3. Calculational model for sample problem. 
Figure 4. Input listing for sample problem. 

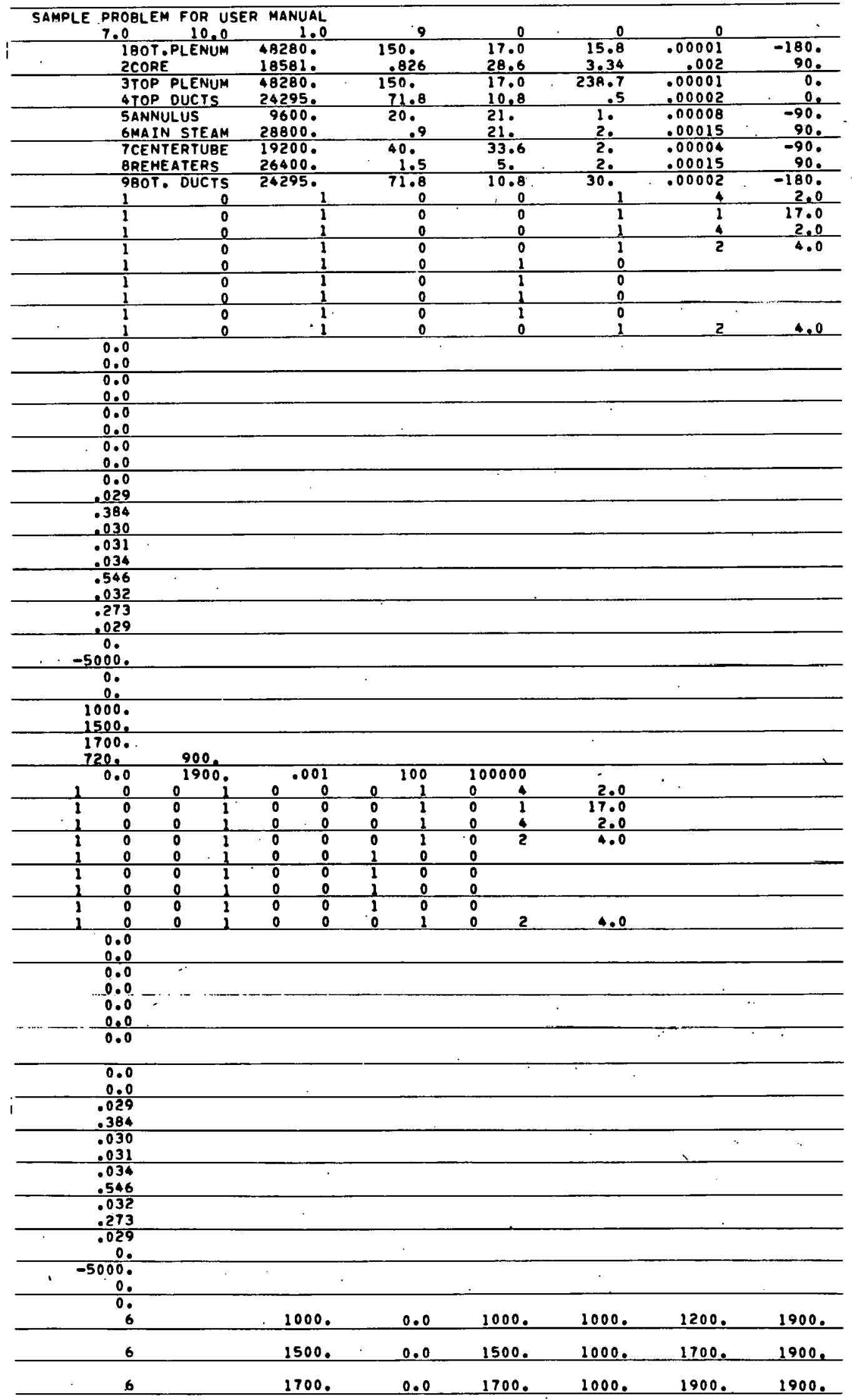


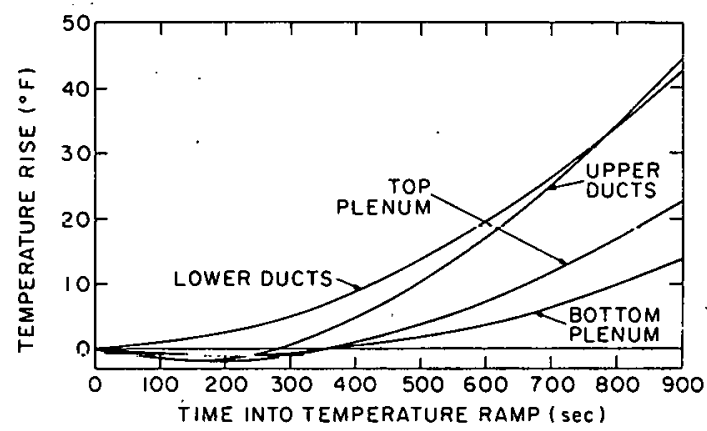

Figure 5. Thermal barrier cover plate temperature response to graphite surface temperature increase. 
Figure 6. Output 11sting for sample problem. 
THIS DRAHLEM THFPE AHF, 9 VIITIMFS/CFGMFMTS

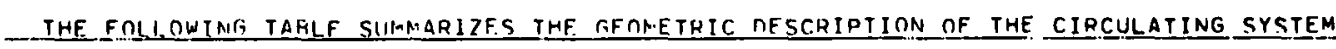

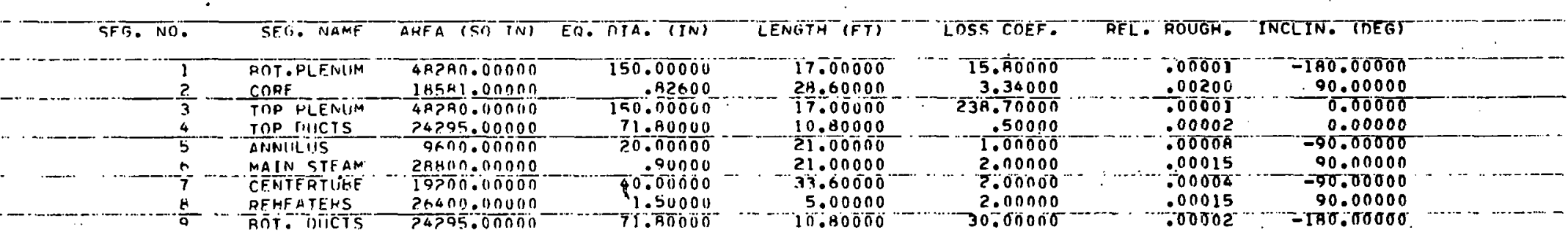

$-180.00000$

THE OPTIONS IISEO IN THE STEAUY STATF PUWTION OF THIS PRORLEM ARE GIVEN IN THF. TABLE RELOW

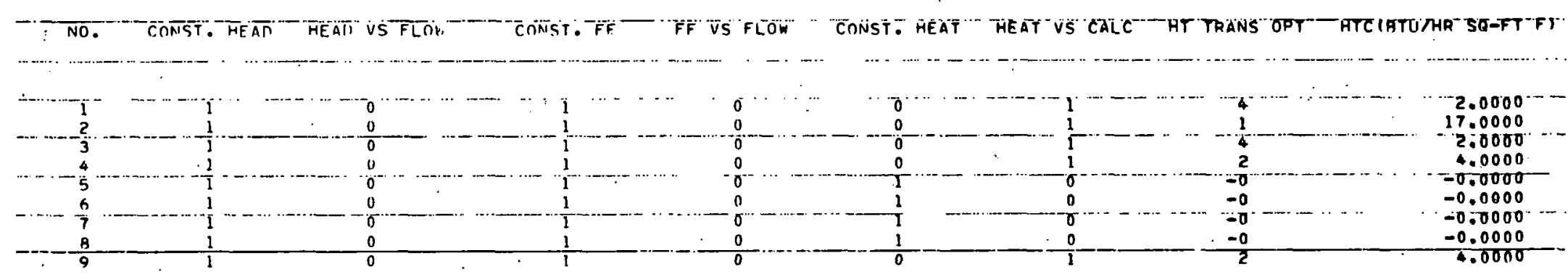

FOR THF STFADY STATF PURTION OF THIS PRORLEM THE CONSTANT PUMP HEAD, FRICTION FACTOR, AND MEAT TRANSFER OPTIONS ARE SHOWN BELON SE.GMENT NO. PUMP HFAA ILAS/SO-FTI FRICTION FACTOR HEAT INPUT (RTUUSEC)

\begin{tabular}{|c|c|c|c|c|c|}
\hline & $?$ & $\begin{array}{l}0.0000 \\
0.0000\end{array}$ & $\begin{array}{l}.0290 \\
.3840\end{array}$ & 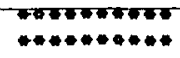 & \\
\hline . & $\frac{1}{3}$ & 0.0000 & $\begin{array}{l}.030 \pi \\
.0310\end{array}$ & - & \\
\hline & $\begin{array}{l}5 \\
6\end{array}$ & $\begin{array}{l}0.0000 \\
0.0000\end{array}$ & $\begin{array}{l}.0360 \\
.5460\end{array}$ & $\begin{array}{r}0.0000 \\
-5000.0000\end{array}$ & \\
\hline & 7 & 0.0000 & .0320 & $0.000 \pi$ & \\
\hline & $\frac{8}{9}$ & 0.0000 & .0290 & 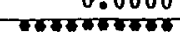 & \\
\hline$\therefore$ & & & & & $\therefore$ \\
\hline
\end{tabular}


Figure 6 (continued).

\begin{tabular}{|c|c|c|c|c|c|c|c|c|}
\hline No. & SFF. NAME. & $\begin{array}{c}\text { INLET TEMP. } \\
\text { (DEG F) }\end{array}$ & $\begin{array}{c}\text { INLF.T PRFS } \\
\text { (PSI) }\end{array}$ & $\begin{array}{l}\text { PUMP HEAU } \\
\text { (PSII) }\end{array}$ & FRIC. FAC. & $\begin{array}{l}\text { H.T. COEF } \\
\text { (A/HR SOFT) }\end{array}$ & $\begin{array}{l}\text { HEAT TRANS } \\
\text { (RTU/SEC) }\end{array}$ & $\begin{array}{l}\text { SIJPF } \text { TEMP. } \\
\text { (OEG F) }\end{array}$ \\
\hline 1 & ROT.PLFNLM & $959.663 \mathrm{~A}$ & $7 ? 0.00170$ & 0.0000 & .0290 & 2.0000 & -29.6343 & 660.8355 \\
\hline$\frac{1}{?}$ & COPF & A5E.27KA & $720.0 n 00$ & 0.0000 & .3840 & 17.0000 & 5632.5781 & 1500.0000 \\
\hline 3 & IOP PLFINUM & $1500.000 n$ & 719.9661 & 0.0000 & .0300 & 2.0000 & -105.6860 & 1091.4386 \\
\hline$\frac{1}{4}$ & TOP nIICTS & 1447.9239 & 719.9660 & 0.0000 & .0310 & 4.0000 & -333.7673 & 1241.3249 \\
\hline 5 & ANNIILUIS & 1449.7791 & 719.9660 & 0.0000 & .0340 & $0 . n n 00$ & 0.0000 & osocososonoso \\
\hline$\frac{3}{6}$ & MATN STEAM & 1444.7791 & 719.9 KG $^{3}$ & 0.0000 & 5460 & 0.0000 & $=5000.0000$ & 860608680008 \\
\hline 7 & CFAITERTURF & $97 k .3505$ & 719.9615 & 0.0000 & .0320 & 0.0000 & 0.0000 & 0000000000000 \\
\hline $\bar{\AA}$ & RE.HF ATERS & ค78. 3505 & 770.0080 & 0.0000 & -.2730 & $n . \overline{n 000}$ & 0.0000 & 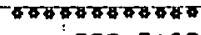 \\
\hline 9 & ROT. MUCTS & 878. 3505 & 720.0011 & 0.0000 & .0290 & 4.0000 & -163.5105 & 757.5432 \\
\hline
\end{tabular}

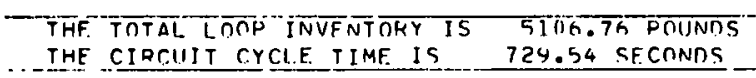

THE RESIIITS FOR A FLOW RATE OF R.ONOUO POINDS PER SECONO ARE AS FOLLOWS

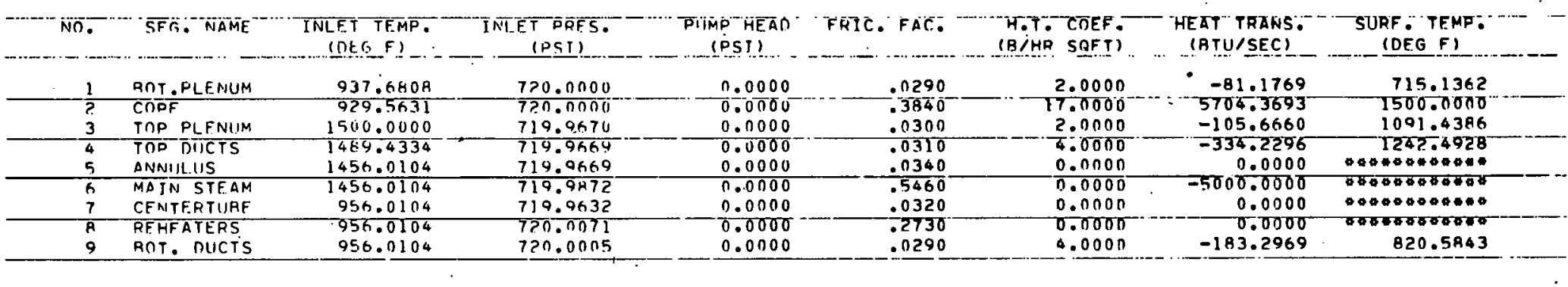

THE TOTAL LOOIP INVENTORY IS $4933.0 \mathrm{~A}$ POUNAS THE CIRCIIT R.YCLE TIME IS 616.63 SFCONDS

THE RESILLTS FOR A FLOW HATE OF 9.0ONOO POINOS PER SECOND ARE AS FOLLOWS

\begin{tabular}{|c|c|c|c|c|c|c|c|c|}
\hline Nn. & SFG. NAMFE. & $\begin{array}{c}\text { INLET TEMP. } \\
\text { (DEG F }\end{array}$ & $\begin{array}{c}\text { INLLET PRES. } \\
\text { (DSI) }\end{array}$ & $\begin{array}{l}\text { PIIMP HEAO } \\
\text { (PSI) }\end{array}$ & FRIC. FAC. & $\begin{array}{l}\text { R.T. CNFF: } \\
\text { (B/HR SOFTI }\end{array}$ & $\begin{array}{l}\text { HEAT TRANS. } \\
\text { (BTU/SEC) }\end{array}$ & $\begin{array}{c}\text { SURF. TEPP. } \\
\text { (DEG F) }\end{array}$ \\
\hline 1 & AOT. PLENIIM & 998.7250 & 720.0000 & 0.0000 & .0290 & 2.0000 & -121.6975 & 757.2458 \\
\hline$?$ & COPE & 987.9074 & 720.0000 & 0.0000 & .3860 & 17.0000 & 5761.0415 & 1500.0000 \\
\hline 3 & TOP PLENIJM & 1500.0000 & 719.9677 & 0.0000 & .0300 & 2.0000 & -105.6660 & 1091.4386 \\
\hline $4^{-}$ & TOD nISCTS & 1490.6075 & 719.9675 & 0.0000 & .0310 & 9.0000 & $=334.5893$ & 1243.4012 \\
\hline 5 & ANNIJLUS & 1460.8662 & $719.9 \times 75$ & 0.0000 & .0340 & 0.0000 & 0.0000 & 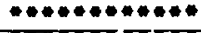 \\
\hline 6 & MAIN STEAM & 1460.8662 & $719.997 \mathrm{~A}$ & 0.0000 & $.5 \overline{460}$ & 0.0000 & -5000.0000 & 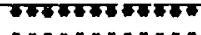 \\
\hline 7 & CENTERTUBE & 1016.4218 & 719.9643 & 0.0000 & .0320 & 0.0000 & 0.0000 & 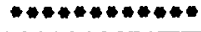 \\
\hline A & REHF ATERS & 1016.4218 & 720.0064 & 0.0000 & .2730 & $0.0000^{\circ}$ & 0.0000 & 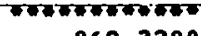 \\
\hline 9 & ROT. DUCTS & 1016.4218 & 720.0001 & 0.0000 & .0290 & 4.0000 & -199.0887 & 869.3280 \\
\hline
\end{tabular}


Figure $6 \%$ (continued).

\begin{tabular}{l} 
THE TOTAL LOOP INVENTORY IS 4 4ROA.36 POINNS \\
THE CIRCIII CYYLE TIME IS \\
\hline
\end{tabular}

THE RESULTS FOR A FLOW HATE OF 10.00000 POIINNS PER SECOND ARE AS FOLLOWS

\begin{tabular}{|c|c|c|c|c|c|c|c|c|}
\hline NO. & SEF. NAME & $\begin{array}{l}\text { INLET TEMP. } \\
\text { (OEG F) } \\
\end{array}$ & $\begin{array}{c}\text { TNI.F.T PRFS. } \\
\text { (PSII) }\end{array}$ & $\begin{array}{l}\text { DIMP HEAD } \\
\text { (PSI!) -: }\end{array}$ & FRIC. FAC. & $\begin{array}{l}\text { H.T. COEF } \\
\text { (B) SHR SOFT) }\end{array}$ & $\begin{array}{c}\text { HEAT TRANS } \\
\text { (ATU/SEC) }\end{array}$ & $\begin{array}{l}\text { SIJRF TEMP. } \\
\text { (DEG F) } \\
\end{array}$ \\
\hline 1 & ROT.PLENUMM & $1047.798 B$ & 720.0000 & 0.0000 & .0290 & 2.0000 & -154.3913 & 790.8632 \\
\hline $\begin{array}{l}2 \\
3\end{array}$ & $\begin{array}{l}\text { CORF } \\
\text { TOP PLENIJM }\end{array}$ & $\begin{array}{l}1035.4475 \\
1500.0000\end{array}$ & $\begin{array}{l}770.0000 \\
719.9581\end{array}$ & $\begin{array}{l}0.0000 \\
0.0000\end{array}$ & $\begin{array}{r}.3940 \\
.0300\end{array}$ & $\begin{array}{r}17.0000 \\
2.0000\end{array}$ & $\begin{array}{r}5806.9062 \\
-105.6660\end{array}$ & $\begin{array}{l}1500.0000 \\
1091.4386\end{array}$ \\
\hline $\begin{array}{l}4 \\
5\end{array}$ & $\begin{array}{l}\text { TOP DUCTS } \\
\text { ANNULUS }\end{array}$ & $\begin{array}{l}1491.5467 \\
1464.7566\end{array}$ & $\begin{array}{l}719.9679 \\
710.9679\end{array}$ & $\begin{array}{l}0.0000 \\
0.0000\end{array}$ & $\begin{array}{r}.0310 \\
.0340\end{array}$ & $\begin{array}{l}4.0000 \\
0.0000\end{array}$ & $\begin{array}{r}-334.8771 \\
0.0000\end{array}$ & 1244.1278 \\
\hline$\frac{5}{6}$ & MAIN STEAM & $\begin{array}{l}1464.7566 \\
1064.7566\end{array}$ & $\begin{array}{l}719.9881 \\
71990650\end{array}$ & $\begin{array}{l}0.0000 \\
0.0000\end{array}$ & $\begin{array}{r}.5460 \\
.0320\end{array}$ & $\begin{array}{l}0.0000 \\
0.0000\end{array}$ & $\begin{array}{r}-5000.00000 \\
0.0000\end{array}$ & 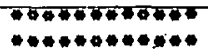 \\
\hline B & $\begin{array}{l}\text { CF.NTERTUAE } \\
\text { DEHFATERS }\end{array}$ & $\frac{1064.7566}{1064.7566}$ & 720.0054 & 0.0000 & .2730 & 0.0000 & -0.0000 & 736050606000 \\
\hline 9 & ROT. DUCTS & 1064.7566 & 719.9997 & 0.0000 & .0290 & 4.0000 & -211.9718 & 908.1443 \\
\hline
\end{tabular}

THE TOTAL LOOP INVENTORY IS 4714.30 POUNNS

\begin{tabular}{l} 
THE TOTAL LOOP INVENTORY IS 4714.39 POUNNS \\
THE CIPCUIT CYCLE TIMF IS 471.44 SFCONNS \\
\hline
\end{tabular}

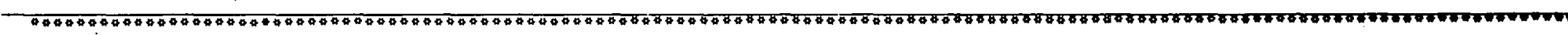
THE LINEAR INTERPOLATION TO OBTAIN 7FP(i PPF SSIIRE DRCP AROUNO THE ENTIRE CYRCTIT RESULTS IN A FLON RATE OF $9.0 B 960$ PNUNUS PER SECONO C.

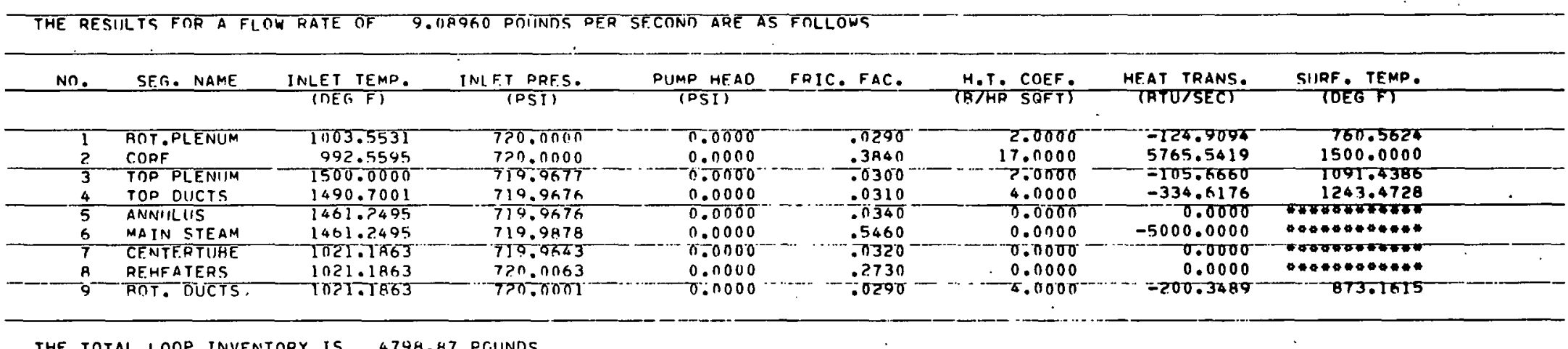

THE TOTAL LOOP INVFNTORY IS 4794.47 POIINNS
THE CIRCIIIT CYCLF. TIMF IS 527.95 CFCIINRS 
Figure 6 (continued).

THE TIME STEP USED IN THIS PROBLEM IS 000100 SECONDS.

A SUMMARY OF VOLUME AND SEGMENT CONDITIONS WILL APPEAR EVERY 100000 TIME STEPS

THE OPTIONS USED IN THE TRANSIENT POATION OF THIS PROBLEM ARE GIVEN IN THE TABLE BELON

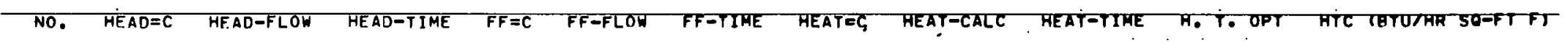

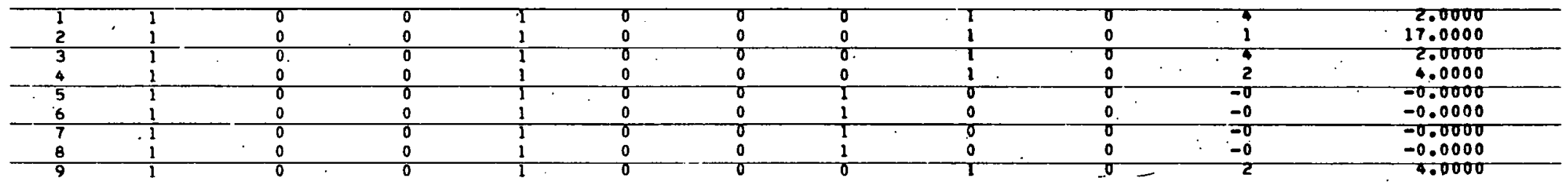

FOR THE TRANSIENT PORTION OF THIS PROBLEM THE CONSTANT PUMP HEAD, FRICTION FACTOR, AND MEAT TRANSFER OPTIONS ARE SHOMN BELON SFGMENT NO. PUMP HEAD (LBS/SO-FT) FRICTION FACTOR HEAT INPUT (ATU/SEC)

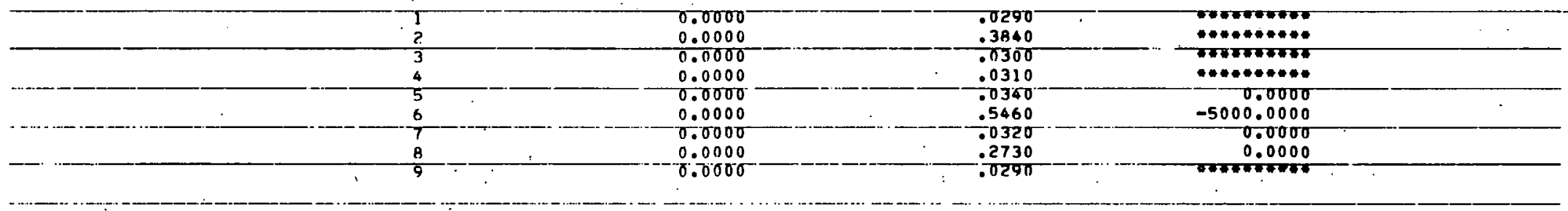

FOR SFGMENT NUMRER 1 THERE ARE 3 DATA PRINTS IN THE GRAPHITE SURFACE TEMPERATURE VERSIS TIME TARLE...

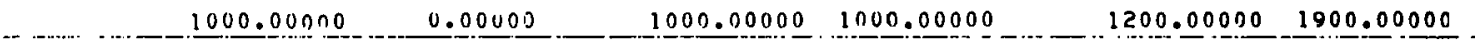

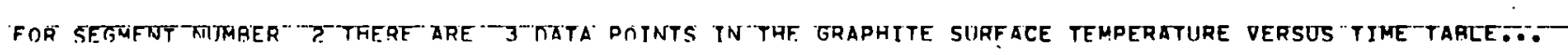

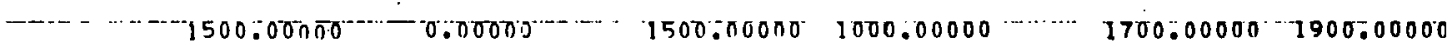

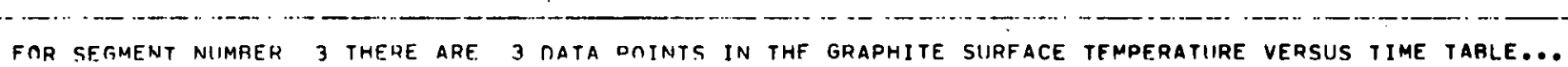
1700.00000
0.00003
$1700.00000 \quad 1000.00000$
$1900.00000 \quad 1900.00000$ 
Figure 6 (continued).

TIME INTO THF TRANSIENT $=0.000$ SFCONDS

\begin{tabular}{|c|c|c|c|c|c|c|c|c|c|c|c|c|}
\hline NO. & SEG. NAME & $\begin{array}{r}\text { INLET TEMP } \\
\text { (DEG F) }\end{array}$ & $\begin{array}{r}\text { INLET PPES } \\
\text { (PSI) }\end{array}$ & $\begin{array}{l}\text { FLOW RATE } \\
\text { (LAS/SEC) }\end{array}$ & $\begin{array}{r}\text { PIIMP AEAD } \\
\text { (PSI) }\end{array}$ & FRIC. & FAC. & $\begin{array}{l}\text { H.T. } \\
\text { SB/HR }\end{array}$ & $\begin{array}{l}\text { COEF: } \\
\text { SOFTI }\end{array}$ & $\begin{array}{r}\text { HEAT TRANS } \\
\text { (BTU/SEC) }\end{array}$ & $\begin{array}{r}\text { SURF TEMP } \\
\text { IOEG F) }\end{array}$ & \\
\hline & & & & - & & & & & & & & \\
\hline & $\begin{array}{l}\text { AOT.PLFNIMA } \\
\text { CORF. }\end{array}$ & $\begin{array}{r}1003.55 \\
992.56\end{array}$ & $\begin{array}{l}720.0000 \\
720.0000\end{array}$ & $\begin{array}{l}9.089604 \\
9.089604\end{array}$ & $\begin{array}{l}0.0000 \\
0.0000\end{array}$ & & $\begin{array}{l}.0290 \\
.3840\end{array}$ & & $\begin{array}{r}2.00 \\
17.00\end{array}$ & $\begin{array}{l}-124.91 \\
5765.54\end{array}$ & $\begin{array}{r}760.56 \\
1500.00\end{array}$ & . \\
\hline $\begin{array}{l}\frac{6}{3} \\
4\end{array}$ & $\begin{array}{l}\text { TOP PLFNIIM } \\
\text { TOD DUICTS }\end{array}$ & $\begin{array}{l}1500.00 \\
1490.70\end{array}$ & $\begin{array}{l}719.9677 \\
719.967 \mathrm{~h}\end{array}$ & $\begin{array}{l}9.089604 \\
9.089604\end{array}$ & $\begin{array}{r}0.0000 \\
0.0000\end{array}$ & & $\begin{array}{r}.0300 \\
.0310\end{array}$ & & $\begin{array}{l}2.00 \\
4.00\end{array}$ & $\begin{array}{l}-105.67 \\
-334.62\end{array}$ & $\begin{array}{l}1091.44 \\
1243.47\end{array}$ & \\
\hline 5 & $\begin{array}{l}\text { ANAIILIIS } \\
\text { MAIN SIEAM }\end{array}$ & $\begin{array}{l}1461.25 \\
1461.25\end{array}$ & $\begin{array}{l}719.9474 \\
71999978\end{array}$ & $\begin{array}{l}9.0896114 \\
9.089604\end{array}$ & $\begin{array}{l}0.0000 \\
0.0000\end{array}$ & & $\begin{array}{l}.0340 \\
.5460\end{array}$ & & $\begin{array}{l}0 . \overline{0} n \\
0.00\end{array}$ & $\begin{array}{r}0.00 \\
-5000.00\end{array}$ & 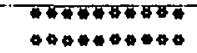 & \\
\hline $\begin{array}{l}7 \\
\\
\end{array}$ & $\begin{array}{l}\text { C.FNTERTUAE } \\
\text { RFHEATERS }\end{array}$ & $\begin{array}{l}\ln 21.19 \\
1021.19\end{array}$ & $\begin{array}{l}719.9643 \\
720.0063\end{array}$ & $\begin{array}{l}9.089604 \\
9.089604\end{array}$ & $\begin{array}{l}0.0000 \\
0.0000\end{array}$ & & $\begin{array}{l}.0321 \\
.2730\end{array}$ & & $\begin{array}{l}0.00 \\
0.00\end{array}$ & $\begin{array}{r}0.00 \\
0.00\end{array}$ & 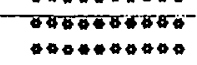 & \\
\hline$\frac{3}{9}$ & BOT. DUCTS & 1021.19 & 720.01001 & $9.0 \times 9604$ & 0.0000 & & .0290 & & 4.00 & -200.35 & -873.16 & \\
\hline
\end{tabular}

TIME INTO THF TRANSIENT $=100.000$ SFCONDS

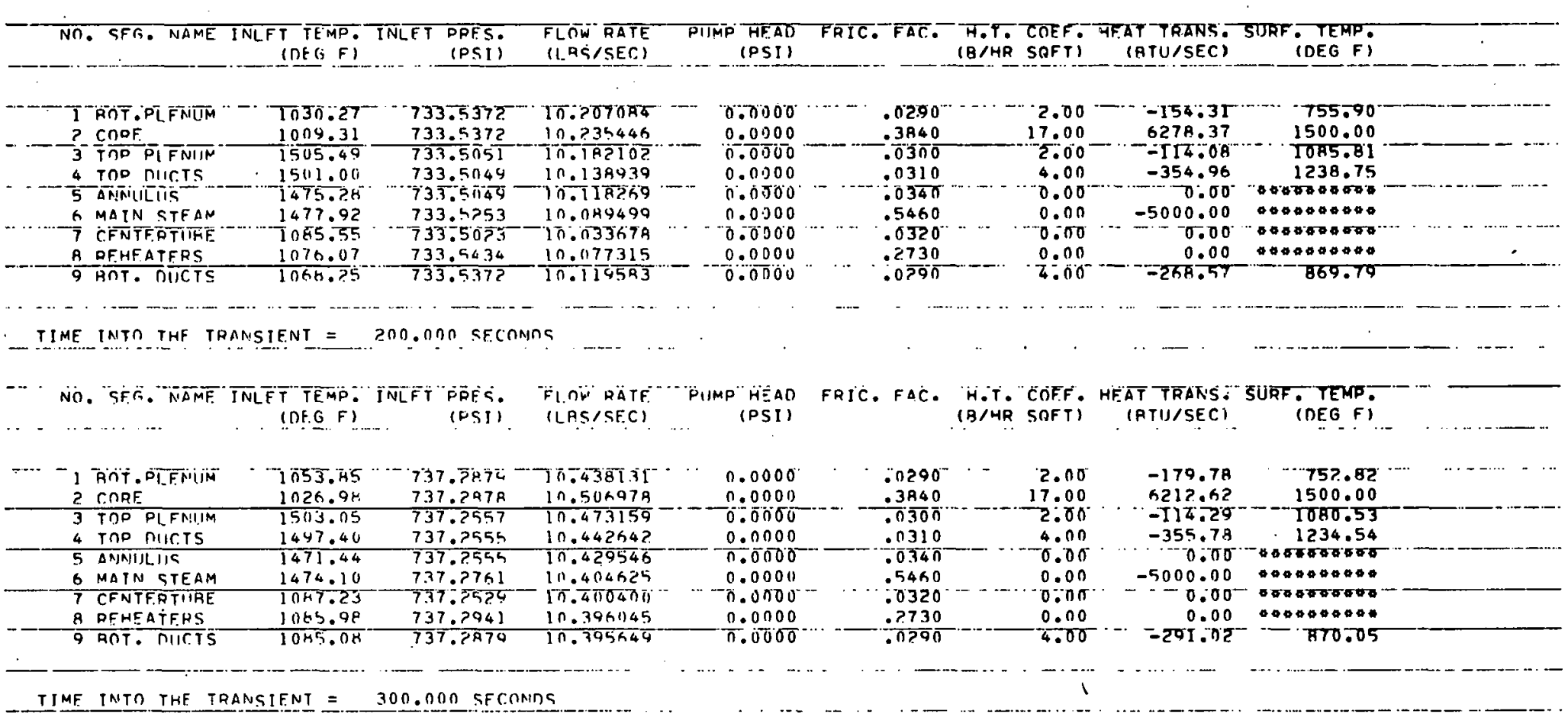

TIME TNTO THE TRANSIENI = 300.000 SFCONOS 
Figure 6 (continued).

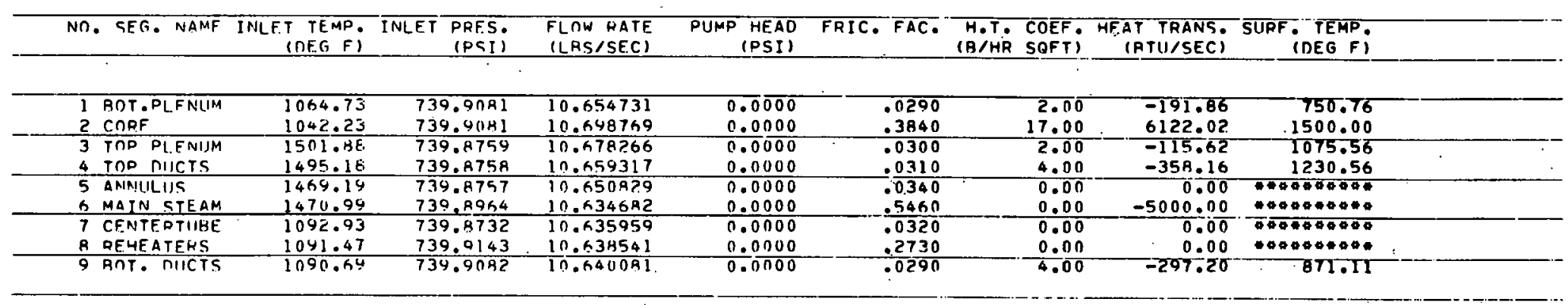

TIME TNTO THE TRANSIENT $=400.000$ SECONOS

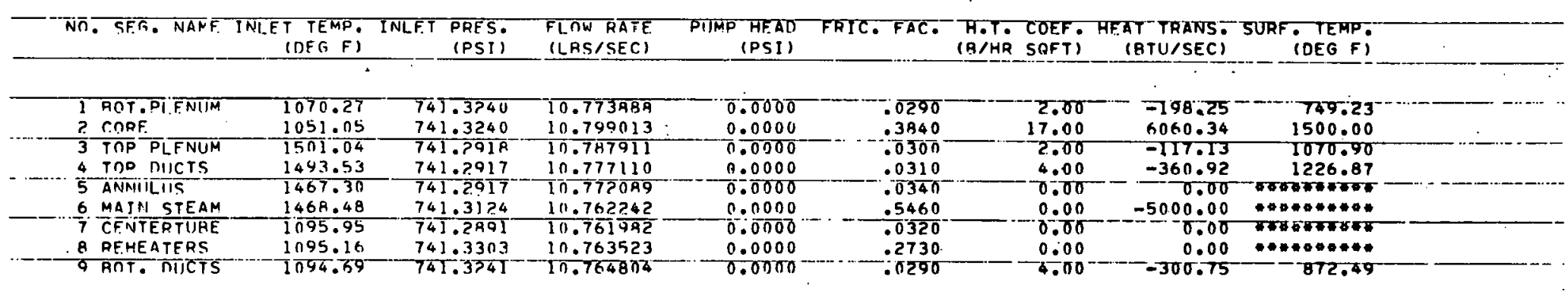

TIME INTO THE TPANSIENT $=500.000$ SFCONNS

NO. SEFG. NAMF. INLET TEMP, INLFT PRES: FLOW TATE PUMP HEAD FRTC. FAC: HOT. COEF. HEAT TRANS: SURF. TEMP. IDERF;

\begin{tabular}{|c|c|c|c|c|c|c|c|c|c|}
\hline & $\begin{array}{l}\text { ADT.PLENUM } \\
\text { CODF }\end{array}$ & $\begin{array}{l}1073.43 \\
105 \mathrm{k} .01\end{array}$ & $\begin{array}{l}742.0760 \\
742.0760\end{array}$ & $\begin{array}{l}10.853323 \\
10.867637\end{array}$ & $\begin{array}{l}0.0000 \\
0.0000\end{array}$ & $\begin{array}{l}.0290 \\
.3840\end{array}$ & $\begin{array}{r}2.00 \\
17.00\end{array}$ & $\begin{array}{l}-202.07 \\
6031.51\end{array}$ & $\begin{array}{r}748.00 \\
1500.00\end{array}$ \\
\hline 3 & $\begin{array}{l}\text { TOP PLFNUM } \\
\text { TOP DIJCTS }\end{array}$ & $\begin{array}{l}1500.56 \\
1492.48\end{array}$ & $\begin{array}{l}742.0438 \\
742.0436\end{array}$ & $\begin{array}{l}10.861695 \\
10.855630\end{array}$ & $\begin{array}{l}0.0000 \\
0.0000\end{array}$ & $\begin{array}{l}.0300 \\
.0310\end{array}$ & $\begin{array}{l}2.00 \\
4.00\end{array}$ & $\begin{array}{l}-118.84 \\
-364.06\end{array}$ & $\begin{array}{l}1066.56 \\
1223.50\end{array}$ \\
\hline 5 & ANINIILIIS & 1465.99 & 742.0436 & 10.852679 & 0.0000 & $\div .0340$ & 0.00 & 0.00 & 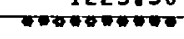 \\
\hline 6 & MAIN STEAM & $146 \pi .72$ & 742.0644 & 10.846820 & 0.0000 & .5460 & 0.00 & -5000.00 & 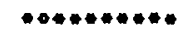 \\
\hline 7 & CFNTFRTUAE & 1097.48 & 742.0411 & 10.8466799 & 0.0000 & .0320 & 0.00 & 0.00 & 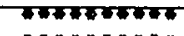 \\
\hline A & REHEATERS & 1097.08 & 742.0 A2. & 10.847402 & .0 .0000 & .2730 & 0.00 & 0.00 & 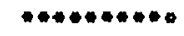 \\
\hline & AnT, nIICTS & 1096.84 & 742.0761 & $10.8479=9$ & 0.0000 & .0290 & 8.00 & -301.63 & 873.98 \\
\hline
\end{tabular}

TIME INTO THF TRANSIENT $=600.000$ SFCONOS

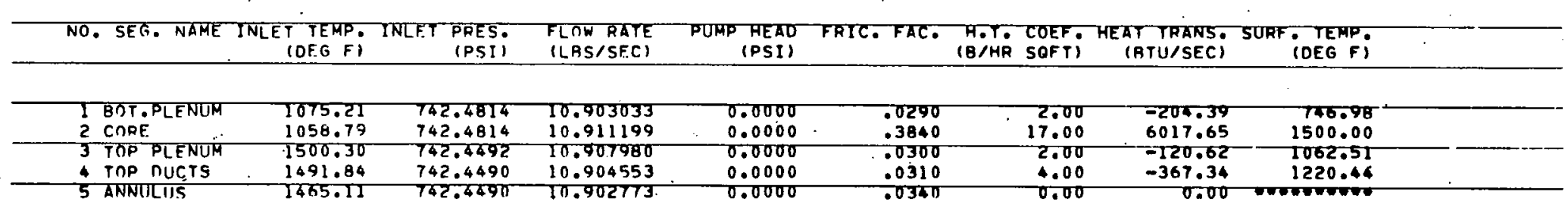


Figure 6 (continued).

\begin{tabular}{|c|c|c|c|c|c|c|c|c|}
\hline $\begin{array}{ll}6 & \text { MAIN STEAM } \\
7 & \text { CENTE.RTURE } \\
8 & \text { REHEATERS } \\
9 & \text { BOT. DUITS } \\
\end{array}$ & $\begin{array}{l}1465.57 \\
1098.32 \\
1098.10 \\
1097.98 \\
\end{array}$ & $\begin{array}{l}742.4698 \\
742.4465 \\
742.4876 \\
747.4815 \\
\end{array}$ & $\begin{array}{l}10.899256 \\
10.899197 \\
10.999574 \\
10.899888 \\
\end{array}$ & $\begin{array}{l}0.0000 \\
0.0000 \\
0.0000 \\
0.0000 \\
\end{array}$ & $\begin{array}{l}.5460 \\
.0320 \\
.2730 \\
.0290 \\
\end{array}$ & $\begin{array}{l}0.00 \\
0.00 \\
0.00 \\
4.00 \\
\end{array}$ & $\begin{array}{r}-5000.00 \\
0.00 \\
0.00 \\
-301.18 \\
\end{array}$ & 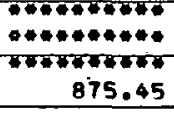 \\
\hline
\end{tabular}

TIMF INTO THE TRANSIENT $=700.000$ SFCONDS

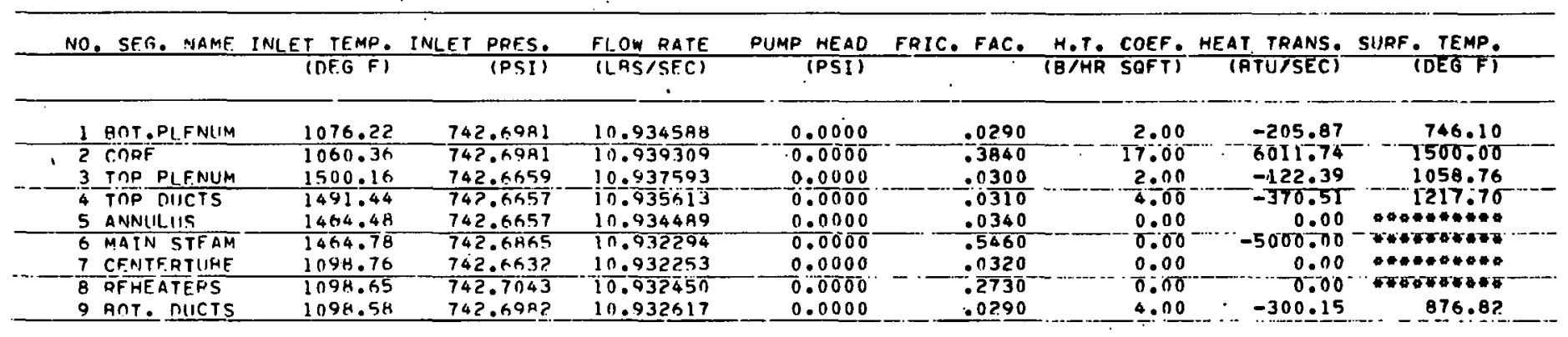

TIME INTO THE TRANSIENT $=800.000$ SFCONNTS

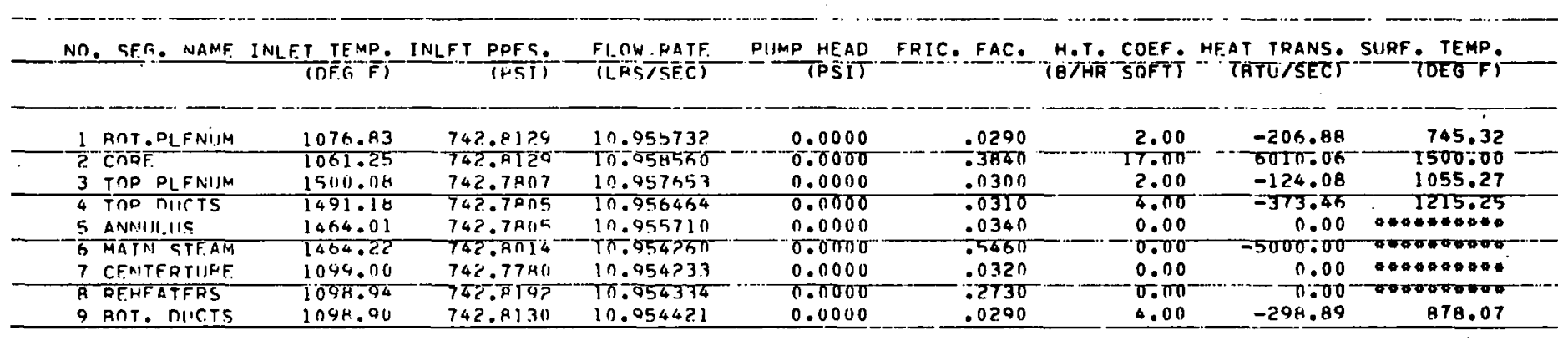

TIME INTO THE TOANSIENT $=900$. तO SO SFCONDS

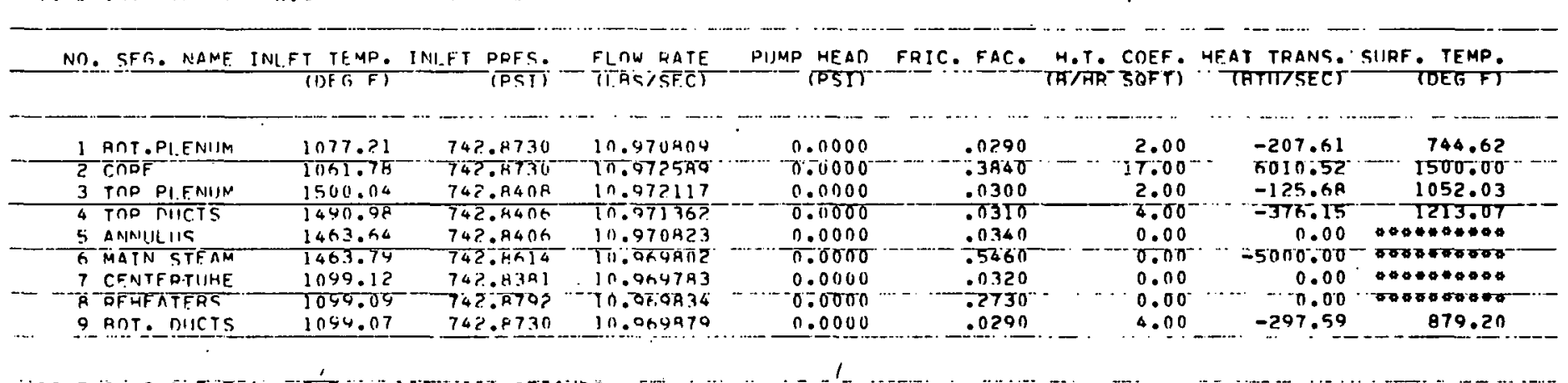

TIME INTO THF TRANSTENT = 1 1000.nON SFCONIS

- 1. 
Figure 6 (continued).

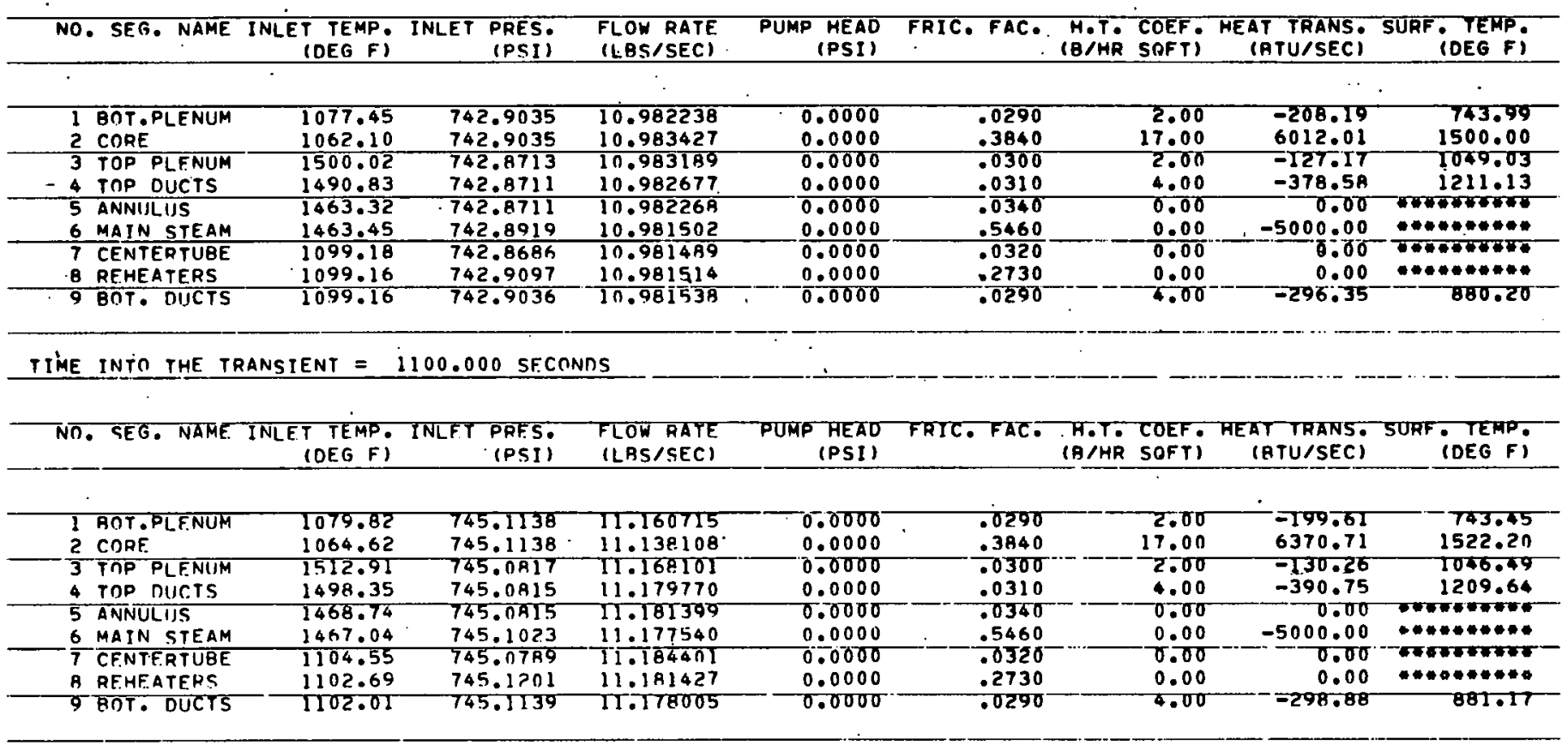

TIME INTO THF TRANSIENT $=1200.000$ SECONDS

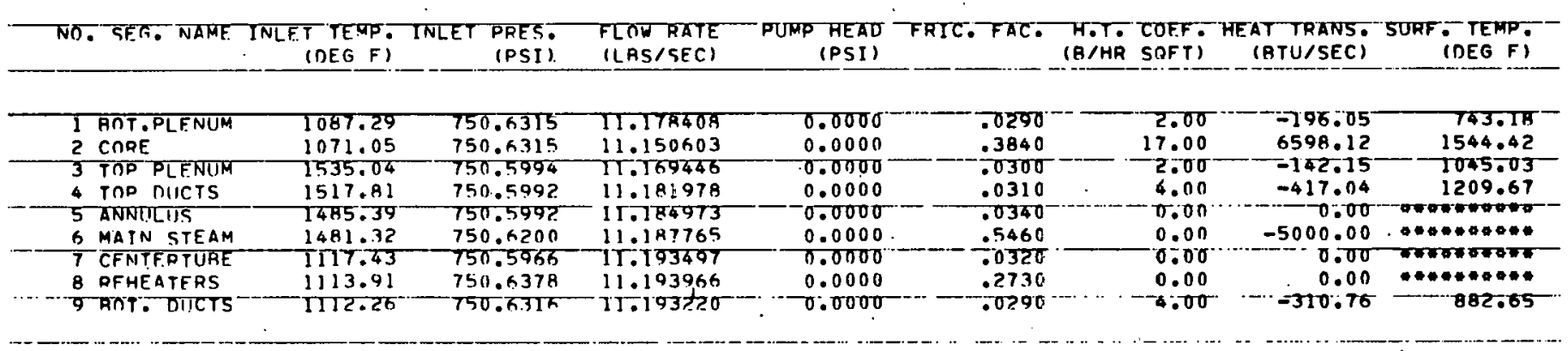

TIME INTO THE TRANSIENT $=1300.000$ SECONNS

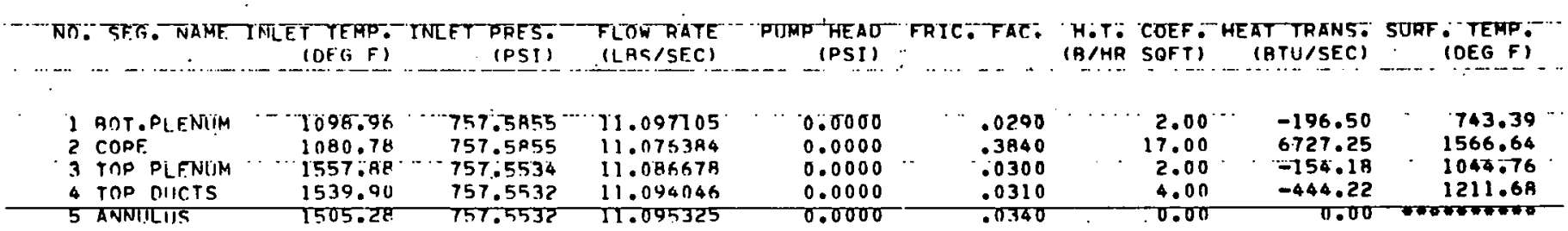


Figure 6 (continued).

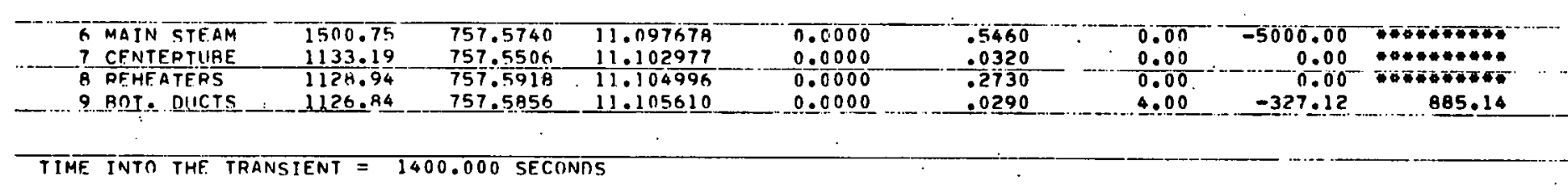

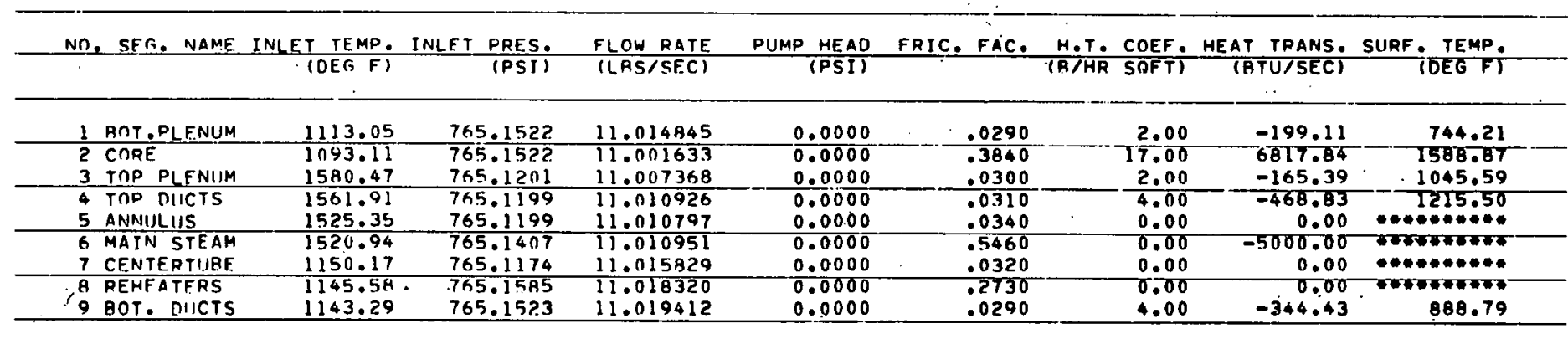

TIME INTO THE TAANSIENT $=1500.000$ SFCONDS

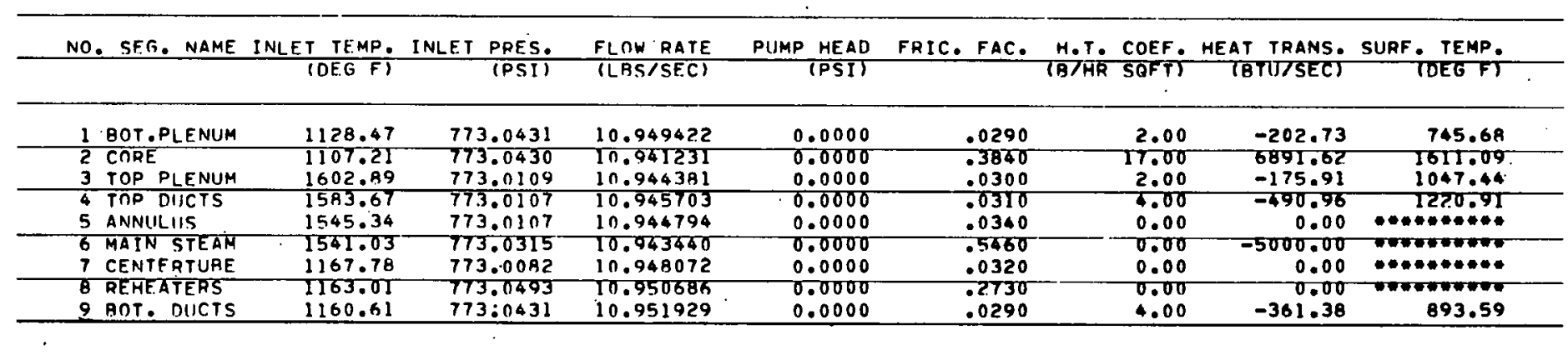

TIME INTO THE TRANSIENT $=1600.000$ SECONDS

\begin{tabular}{|c|c|c|c|c|c|c|c|c|c|}
\hline m. SEF, NAME & $\frac{\text { INLET TEMP. }}{\text { (DEG F) }}$ & INLET & $\frac{T \text { PRES. }}{\text { (PSI) }}$ & $\begin{array}{l}\text { FLOW RATE } \\
\text { (LBS/SEC) }\end{array}$ & $\frac{\text { PUMP HEAD }}{\text { (PSI) }}$ & FRIC. FAC. & $\begin{array}{l}\text { H.T. COEF. } \\
\text { TBTHA SOFYT }\end{array}$ & $\frac{\text { HEAT TRANS. }}{\text { (BPU/SEC }}$ & $\frac{\text { SURF . TEMP. }}{\text { TOEG FT }}$ \\
\hline $\begin{array}{ll}1 & \text { AOT . PLFNUM } \\
2 & \text { CORE } \\
3 & \text { TOP PLENUM } \\
4 & \text { TOP DUICTS } \\
5 & \text { ANNULUS } \\
6 & \text { MAIN STEAM } \\
7 & \text { CENTERTUBE } \\
8 & \text { AENEATERS } \\
9 & \text { BOT. DUCTS } \\
\end{array}$ & $\begin{array}{l}1144.65 \\
1122.40 \\
1625.21 \\
1605.30 \\
1565.32 \\
1561.07 \\
1185.80 \\
1180.91 \\
1178.43 \\
\end{array}$ & $\begin{array}{l}78 \\
78 \\
78 \\
78 \\
78 \\
78 \\
78 \\
78 \\
78 \\
\end{array}$ & $\begin{array}{l}81.1349 \\
81.1349 \\
81.1028 \\
81.1026 \\
81.1026 \\
81.1234 \\
81.1001 \\
81.1412 \\
81.1350\end{array}$ & $\begin{array}{l}10.895457 \\
10.890305 \\
10.891857 \\
10.891851 \\
10.890529 \\
10.888351 \\
10.892817 \\
10.495472 \\
10.896778\end{array}$ & $\begin{array}{l}0.0000 \\
0.0000 \\
0.0000 \\
0.0000 \\
0.0000 \\
0.0000 \\
0.0000 \\
0.0000 \\
0.0000\end{array}$ & $\begin{array}{l}.0290 \\
.3860 \\
.0300 \\
.0310 \\
.0340 \\
.5460 \\
.0320 \\
.27350 \\
.0290\end{array}$ & $\begin{array}{r}2.00 \\
17.00 \\
2.00 \\
4.00 \\
0.00 \\
0.00 \\
0.00 \\
0.00 \\
4.00\end{array}$ & $\begin{array}{r}-206.79 \\
6955.25 \\
-165.87 \\
-511.05 \\
0.00 \\
-5000.00 \\
0.00 \\
0.00 \\
-377.57\end{array}$ & 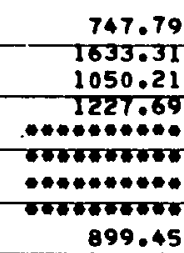 \\
\hline
\end{tabular}

TIME INTO THE TRANSIENT $=1700.000$ SECOMDS 
Figure 6 (continued).

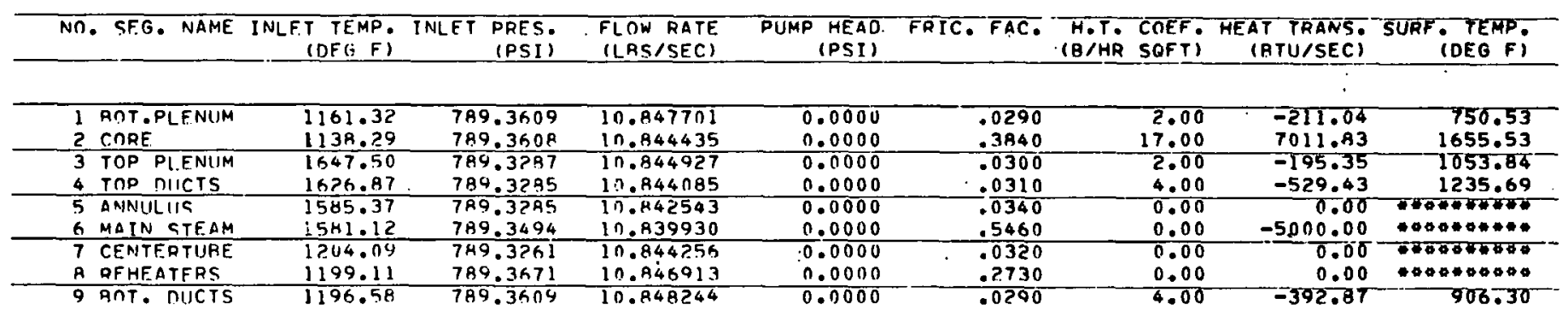

TIME INTA THE THANSIENT $=1800.000$ SFCONOS

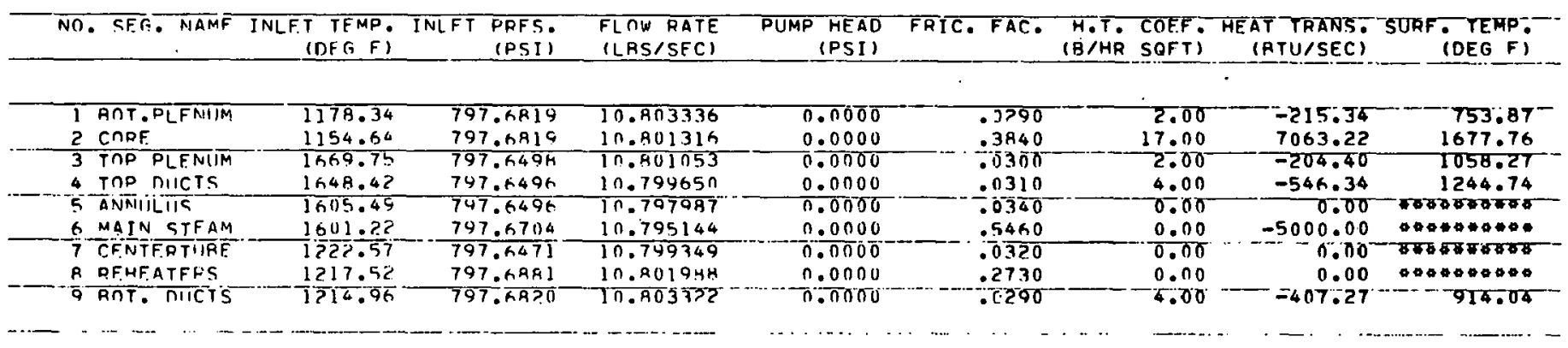

TIMF INTO THF THANSIFNT $=1900.000$ SECONIS

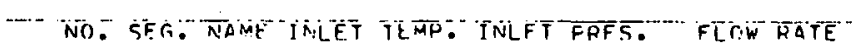

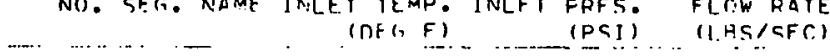

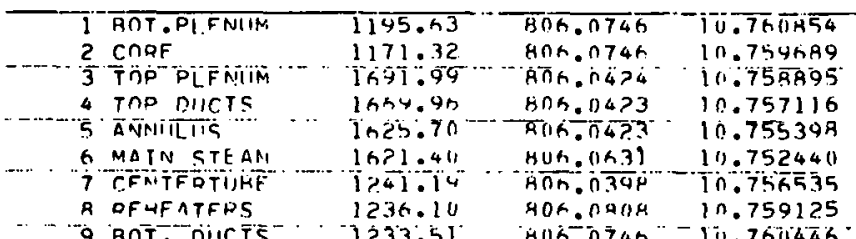

PIJMP HEAL FHIC: FAC: (PSI)

$$
\begin{aligned}
& 0.0000 \\
& 0.0000 \\
& 0.01000 \\
& 0.0000 \\
& 0.0000 \\
& 0.0000 \\
& 0.00000 \\
& 0.00000
\end{aligned}
$$$$
0.0000
$$

Hit. COEF, HEAT TRANS: SUPF TEMP;
(B/HR SOFT)
(RTIJ/SEC)

$\begin{array}{rr}.0290 & 2.00 \\ .3340 & 17.00 \\ .0300 & 2.00 \\ .0330 & 4.00 \\ .03340 & 0.00 \\ .5460 & 0.00 \\ .0320 & 0.00 \\ .2730 & 0.00 \\ .0790 & 4.00\end{array}$

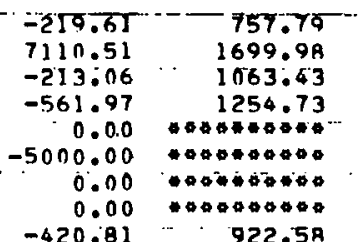




\section{REFERENCES}

1. G. M. Schultz, "Large HTGR Steam Generator Design Verification and Support Programs," GA-Al2808 (GA-LTR-5), Vo1. II, December 1973, Chap. 3.

2. K. E. Schwartztrauber and F. A. Silady, "CORCON: A Program for Analysis of HTGR Core Heatup Transients," GA-Al2868 (GA-LTR-13), July 1974.

3. A. Bardia and R. C. Potter, "TAP: A Program for Analysis of HTGR Nuclear Steam Supply System Performance Transients," GA-A13248 (GA-LTR-21), January 1976.

4. H. W. Chi and G. J. Malek, "Description of the Reactor Emergency Cooling Analysis Code, RECA," GA-10273, August 1970.

5. J. S. Gilbert, et al, "User's Manual for the Composite HTGR Analysis Program (CHAP-1)," LA-NUREG-6576-M, November 1976, Draft.

6. W. Pfeiffer, et al, "POKE, A Gas-Cooled Reactor Flow and Thermal Analysis Code," GA-10226, July 1970.

7. G. J. Malek, "Development of the Flow Analysis Code FLAC," GA-9482, June 1969.

8. L. F. Moody, "Friction Factors for Pipe Flow," A.S.M.E. Transactions, Vo1. 66 , No. 8, Novemver 1944, p. 671.

9. J. R. Welty, C. E. Wicks, and R. E. Wilson, "Fundamentals of Momentum, Heat and Mass Transfer," John Wiley and Sons, 1969, Chap. 5.

10. J. C. Hunsaker and B. G. Rightmire, "Engineering Applications of Fluid Mechanics," McGraw-Hi11, 1947, Chap. V.

11. "User's Manual for RELAP3B-MOD 110. A Reactor System Transient Code," BNL-NUREG-22011, September 1976. 
12. R. C. Binder, "Fluid Mechanics," 2nd Ed., Prentice-Ha11, 1949, Chap. 7.

13. J. S. Kaufman, "Large HTGR Steam Generator Design Verification and Support Programs," GA-A-12808 (GA-LTR-5), Vol. IV, December 1973, Chap. 4. 


\section{APPENDIX.A :}

Subroutine HTRNSFR

This appendix describes the details of the heat transfer models incorporated in subroutine HTRNSFR. Subroutine HTRNSFR is the only portion of SODEME that is not programmed to allow for an arbitrary problem definition. Instead it has been coded to simulate the geometry and materials of the 3000 MWth HTGR design. In particular, the options the user has in utilizing this subroutine deal with heat transfer in either the core, the cross ducts, the plena, or the steam generators. Thus this part of SODEMME is "hard wired" for 3000 MWth HTGR application; to simulate problems in other systems the user must avoid utilizing this subroutine (which can be done for problems in which the heat transfer in each segment is given explicitly) or alternatively, provide a substitute subprogram that solves the heat transfer problems germane to those systems.

Subroutine HTRNSFR has two major tasks that it must perform for any segment :

- compute the heat transferred to the helium

- compute the surface temperature in that segment.

Further, the subroutine must perform these calculations during steady state operation when SODEMME is establishing the initial conditions, and then later, during the transient portion, it must supply these two variables for transient heat transfer conditions. A total of ten options, four for steady state and six for transient conditions, have been coded into HTRNSFR to accomplish this. These ten options are in addition to the two simpler ones 
at the disposal of the user; viz. an arbitrary constant amount of heat transferred to the helium or alternatively, an arbitrary temporal function specified during input. The remainder of Appendix $A$ is devoted to describing the four steady state models first, and then the six transient models.

\section{Steady State Options}

\section{Option 1}

The first option available in HTRNSFR is the only one that is not tailored to any particular kind of HTGR component. It calculates heat transfer in a constant flow area channel having a constant surface temperature. If it is assumed that the heat transfer coefficient and gas properties are independent of position along such a channel, the outlet gas temperature can be found in terms of the other parameters of the flow system

$$
\mathrm{T}_{0}=\mathrm{T}_{\mathrm{s}}+\left(\mathrm{T}_{i}-\mathrm{T}_{\mathrm{s}}\right) \exp -\left(\mathrm{hpl} / \mathrm{w} \mathrm{C}_{\mathrm{p}}\right)
$$

For this option the channel surface temperature must be specified during input; it is returned by the subroutine without alteration. The heat transferred into the gas is simply calculated from

$$
q=w C_{p}\left(T_{o}-T_{i}\right)
$$

\section{Option 2}

This option is used to calculate heat transfer and surface temperatures in ducts lined with the thermal barrier used in the HTGR. It is appropriate to use this option when it is desired to simulate the cross ducts that connect the plena to the steam generator cavities.

It is assumed that the thermal barrier consists of a $1 / 4$ inch thick 
Hastelloy cover plate over a 2.3/4 inch thick kaowool blanket. The side of the kaowool blanket away from the cover plate is cooled by water circulated through the liner cooling system. It is assumed that this side is always maintained at $100^{\circ} \mathrm{F}$. The thermal conductivity of the kaowool is taken to be linear with temperature over the range likely to be of interest in practical applications

$$
\mathrm{k}=\mathrm{a}+\mathrm{b} \mathrm{T} \text {. }
$$

In the units used internally by the code a good fit to kaowool thermal conductivity data is achieved when

$$
\begin{aligned}
& a=1.654 \times 10^{-5} \\
& b=3.404 \times 10^{-8}
\end{aligned}
$$

By matching the heat flux across the interface between the helium and the cover plate to the heat flux through the insulation, the cover plate temperature (i.e: the surface temperature) can be determined. Continuity of heat flux results in a quadratic equation for $T_{S}$

$$
\frac{b}{2 \Delta x} T_{s}^{2}+\left(\frac{a}{\Delta x}+h\right) T_{s}-\frac{a}{\Delta x} T_{c}-\frac{b}{2 \Delta x} T_{c}^{2}-h T_{i}=0
$$

Once the surface temperature is obtained the heat transferred to the helium is found simply from the convection equation

$$
q=h p \ell\left(T_{s}-T_{i}\right)
$$

\section{Option 3}

This option addresses heat transfer in the plena of the HTGR. The plenum is modeled as two circular surfaces, one a graphite surface (the reflector), and the other a thermal barrier having exactly the same characteristics as the thermal barrier lining the ducts. The heat transfer and 
surface temperature calculation for the latter is therefore the same as in Option 2.

In this option, however, the amount of heat transferred from the reflector to the helium must be specified during input preparation. This amount of heat is assumed independent of the heat transfer situation prevailing in the thermal barrier. The surface temperature of the reflector is then found from the convection equation. Finally, the surface temperature of the graphite is compared to the surface temperature of the cover plate on the thermal barrier. The lesser of these two temperatures is printed in the output as the relevant surface temperature*.

\section{Option 4}

Option 4 is very similar to Option 3 in that heat transfer in the plena is of interest. The only difference between this model and the one in Option 3 is that in this model the surface temperature of the reflector, instead of the amount of heat transferred from the reflector, must be . specified during input preparation. The heat transferred from the thermal barrier is again computed as in Options 2 and 3 and the heat transferred from the reflector is computed from the convection equation. Here again the reported surface temperature is the smaller of the two surface temperatures (i.e. the thermal harrier cover plate or the graphite reflector).

\footnotetext{
*The lower surface temperature is relevant in this version of the code because interest is focused on the possibility of fission product condensation on PCRV internals.
} 


\section{Transient Options}

These options compute transient heat transfer in various components of an HTGR. The next four options are the transient analogs of the four options outlined above. The fifth one is specific to the steam generators in the HTGR and the sixth option is used for the core when the reactor power is specified as a function of time. In Options 2-6 the options first compute the'steady state solutions consistent with the steady state boundary conditions and then use these as the initial conditions for the transient portions. Since an explicit method of solution is employed some attention must be paid to the time step used so as not to violate stability criteria: The equations used in these options will be outlined in some detail so that the limitations on the allowable time step will be apparent. It will be seen that the upper limit on the time step for transient heat transfer calculations is many time larger than the time step that would normally be used for the other parts of the SODEMME program and so this consideration does not impose an undue restriction on the user.

\section{Option 1}

This option calculates heat transfer to a fluid flowing in a constant flow area channel whose surface temperature is constant along the entire channel length but is an arbitrary function of time. If the same assumptions concerning the other parameters are made as in Option 1 in the steady state model, it is easy to show that Equation $(A-1)$ is valid for the timedependent case if $T_{S}$ is replaced by its time-dependent equivalent, $T_{S}(t)$. The amount of heat transferred to the helium during any time step is likewise still correctly given by Equation (A-2), where $T_{0}$ is replaced by its equivalent, $T_{0}(t)$. 


\section{Option 2}

This option computes the transient behavior of the thermal barrier lining the duct walls in an HTGR. The same assumptions regarding size and thermal properties of the barrier that are used in 0ption 2 during steady state are used again here and the surface of the kaowool opposite the cover plate is assumed to be kept always at $100^{\circ} \mathrm{F}$, also as in the steady state case.

First the initial thermal barrier cover plate temperature is calculated, using the same relationship as during steady state [i.e. Equation $(A-4)]$. After obtaining this temperature, the assumption is made that all of the thermal barrier capacitance is in the cover plate and all of the thermal resistance is in the kaowool. It is further assumed, for the transient part of the analysis, that the thermal conductivity of the kaowool is temperature-independent. Using an explicit forward differencing technique it is easy to set up the heat balance for the cover plate. The cover plate temperature is updated by repeatedly applying the resulting equation:

$$
\mathrm{T}_{\mathrm{s}}^{\prime}=\left(\mathrm{h}_{\mathrm{f}}+\frac{\mathrm{k}}{\Delta \mathrm{x}} \mathrm{T}_{\mathrm{c}}\right) \frac{\Delta \mathrm{t}}{\delta \rho \mathrm{C}_{\mathrm{s}}}+\left[1-\left(\mathrm{h}+\frac{\mathrm{k}}{\Delta \mathrm{x}}\right) \frac{\Delta \mathrm{t}}{\delta \rho \mathrm{C}_{\mathrm{s}}}\right] \mathrm{T}_{\mathrm{s}}
$$

This relation also yields the stability criterion for the maximum allowable time step. Since the term in brackets in Equation (A-6) must be positive for all values of the parameters the time step must obey inequality (A-7)

$$
\Delta t \leq \frac{\delta \rho C_{s}}{\left(h+\frac{k}{\Delta x}\right)}
$$

The heat transfer rate is obtained at any time by applying the convective law to the updated cover plate surface temperature. 


\section{Option 3}

This option is the time-dependent analog of Option 3 among the steady state algorithms. The thermal barrier cover plate temperature is found as a function of time exactly as in Option 2 above; i.e. by first obtaining the steady state solution and then stepping along in time using a finite difference technique. The contribution of the reflector to the heat input is specified as a function of time explicitly and so HTRNSFR simply adds this component to the heat transferred by the thermal barrier.

The surface temperature of the thermal barrier is determined as just explained. The concomitant reflector surface temperature is obtained from the convection equation. As in the steady state situation, the lesser of these two surface temperatures is printed in the output under that designation.

\section{Option 4}

This option is the time-dependent analog of Option 4 among the steady state algorithms. The treatment of the thermal insulation is once again as in 0ption 2 above but it is the surface temperature of the reflector, rather than its heat flow, that is specified in the input as a function of time. Utilization of the convection equation supplies the latter quantity. The surface temperature that is printed is the lesser of the two surface temperatures, as before.

\section{Option 5}

This option provides a simple model for the main steam generators during transients. There is no steady state analog; the heat transferred during the steady state portion of the computation must be a constant, specified as input. If the heat transfer during the transient portion is 
not specified as some constant or as an explicit function of time, this option will compute heat transfer in the steam generators based on the following premises:

- The steam generators and reheaters are homogenized into 6 parallel, 72 foot long assemblies containing a total of $3.15 \times 10^{6}$ pounds of steel and having a total of 201600 square feet of heat transfer surface.

- The steam generators and reheaters have no water or steam in the modules. Any heat transfer that takes place is between steel and helium only.

- There is no temperature variation radially through the tube and/or shell walls. All resistance to heat flow takes place in the helium boundary layer.

The programming is such that any initial steel temperature may be specified during input to serve as the initial condition for each segment using this option. If an initial temperature is not specified, the code" proceeds by assigning the surrounding helium gas temperature to the steel. Using a forward differencing technique similar to the one used for the thermal barrier, the heat balance for the heat exchanger metal yields

$$
T_{S}^{\prime}=\frac{h A T_{f}}{M C_{S}} \Delta t+\left(1-\frac{h A}{M C_{S}} \Delta t\right) T_{S}
$$

The maximum allowable time step is found, as before, by observing that the term in parentheses in Equation (A-8) must always be positive. Therefore

$$
\Delta t \leq \frac{M C_{s}}{h A}
$$




\section{Option 6}

For some applications of the code the core power as a function of time may be the variable specified instead of the core graphite surface temperature. Option 6 has been included in HTRNSFR for this eventuality. This option utilizes an "equivalent" unit cell which has the heat transfer properties of the original unit cell. It first computes the steady state temperature distribution through the fuel and graphite and then, from this initial temperature profile, the code proceeds to obtain the transient temperature distribution, again by using a forward difference method.

Figure A-1 shows a representative unit cell from the core of an HTGR. Although the thermal problem is two dimensional in principle, studies have shown that in practice it can be closely approximated by a one-dimensional model. This comes about because the graphite in the right angle region of the unit cell is not influential in conducting heat from the fuel to the coolant and can be almost completely neglected. This option therefore utilizes the pseudo-one-dimensional equivalent unit cell shown in Figure A-2. In this equivalent cell the fuel rod has been kept intact and the lengths of the fuel-graphite interface, the coolant-graphite interface, and the graphite web are preserved. The only important parameter that is changed is the volume of graphite. Since this is important only as a thermal inertia term during transients, the thermal diffusivity of the graphite was modified to compensate for the volume change resulting from this mapping into an equivalent cell.

In this conduction model the fuel is divided into five concentric cylindrical regions of equal width and the graphite is divided into four 
equal width slabs. The steady state, finite difference solution for each of the resulting ten nodal points is easily obtained by application of the Poisson Equation. The transient heat conduction equation for an internal point, using forward differences, is in general

$$
k_{\ell} A_{\ell} \frac{T_{\ell}-T}{S_{\ell}}+k_{r} A_{r} \frac{T_{r}-T}{S_{r}}+g V=\rho C_{S} V \frac{T^{\prime}-T}{\Delta t}
$$

Solving this equation for $T^{\prime}$ results in a linear equation in $T_{\ell}, T_{r}$ and $\mathrm{T}$ in which the coefficient of $\mathrm{T}$ is

$$
1-\frac{k_{\ell} A_{\ell}}{\rho C_{S} S_{\ell} v} \Delta t-\frac{k_{r}^{A} A_{r}}{\rho C_{S} s_{r} V} \Delta t
$$

For reasons of numerical stability this coefficient must always be positive and that consideration yields the limitation on the size of the time step

$$
\Delta t \leq \frac{\rho C_{s} v}{\frac{k_{\ell} A_{\ell}}{S_{\ell}}+\frac{k_{r} A_{r}}{S_{r}}}
$$

Similarly, for a point on the graphite-coolant interface, a similar heat balance results in another stability criterion

$$
\Delta t \leq \frac{\rho C_{s} V}{\frac{k_{\ell} A_{\ell}}{S_{\ell}}+h A_{r}}
$$

For the numerical values appropriate to the HTGR core materials and geometry the more restrictive of these two conditions occurs at the graphitecoolant interface (Equation A-13) but even there the critical time step is about 175 milliseconds. This is two orders of magnitude higher than the typical time steps used in the other subroutines in SODEMME and so is not in any sense debilitating in terms of executing the code. 


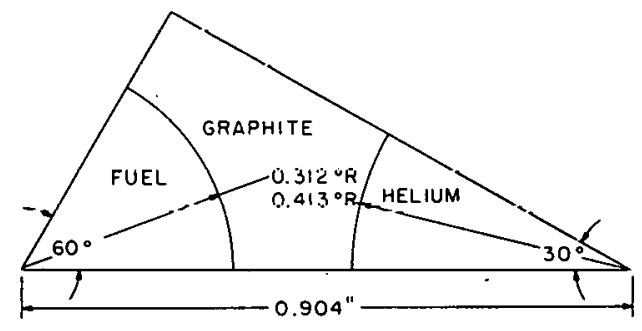

Figure A-1. HTGR unit cell.

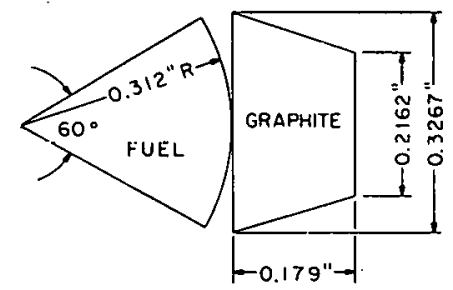

Figure A-2. Equivalent one-dimensional cell. 


\section{APPENDIX B}

Geometric Kelations in Plena

A system containing a circulating gas is represented by SODEMME as a series of connected segments, each of which is cylindrical (although not necessarily circular) and has an individual flow area, equivalent hydraulic diameter, and length. These three parameters, among other descriptive geometric items, are required as input to the program. For most components of an HTGR, such as the coolant channels, cross ducts, and steam generators, the three parameters are easily evaluated from their basic definitions. For a component such as the plenum, however, some care must be exercised In defining these parameters so that their definition is consistent with the intent of the algorithms in the code.

The flow area, equivalent diameter and length are used by the program to derive three other useful quantities for each segment: the wetted perimeter, the volume, and the heat transfer area. For each segment the code computes these derived quantities in terms of the input parameters by using

$$
\begin{aligned}
& \mathrm{p}=4 \mathrm{~A} / \mathrm{D} \\
& \mathrm{V}=\mathrm{Al} \\
& \mathrm{A}_{\mathrm{h}}=4 \mathrm{Al} / \mathrm{D}
\end{aligned}
$$

Equations (B-1) are obvious for items such as coolant channels, cross ducts, and other components through which the flow is in a generally axial direction. The question becomes: what input values of $A, D$, and $\ell$ are appropriate for the plena, so that physically meaningful values of $p, V$, and $A_{h}$ will ensue? 
If it is assumed that the fluid flows in a generally radial direction in the plenum, which is modeled as a circular cylinder of radius $R$ and height $d$, suitable values of $p, V$, and $A_{h}$ in terms of $R$ and $d$ can be formulatẹd

$$
\begin{aligned}
& \mathrm{p}=2 \pi \mathrm{R} \\
& \mathrm{V}=\pi \mathrm{R}^{2} \mathrm{~d} \\
& \mathrm{~A}_{\mathrm{h}}=2 \pi \mathrm{R}^{2}
\end{aligned}
$$

Combining Equations ( $B-1)$ with $(B-2)$ makes it possible to solve for $A, D$, and $\ell$ in terms of $R$ and $d$. The result is

$$
\begin{aligned}
& A=\pi R d \\
& D=2 d \\
& \ell=R
\end{aligned}
$$

Equations (B-3) should therefore be used when preparing input values of A, $D$, and $\ell$ for segments representing plena. In this way the coding will yield numerical values of $p, V$, and $A_{h}$ which are meaningful within the context of the physical problem being simulated. Furthermore, these relations are consistent with intuition and hence are easily remembered. For radial flow from the center of a cylinder to the outside radius, the simplest definitions for flow area, equivalent diameter, and length along which the fluid must travel, coincide exactly with the relationships shown in Equations (B-3). 


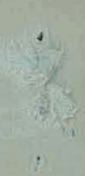

4 